\title{
The Evolution of Heat by Wounded Plants.
}

\author{
BY \\ HERBERT MAULE RICHARDS.
}

With Woodcuts $\mathbf{r}$ and 2.

$\mathrm{T}^{\mathrm{H}}$

HE capability of plants to respond by increased vital activities to different forms of injury is a fact which is well recognized, although the attending phenomena have not in all cases been thoroughly investigated. It is not difficult to enumerate a number of instances where, in quite dissimilar ways, a definite reaction towards abnormal conditions has been observed. There may be mentioned, for instance, the formation of callus and of corky tissue, which follows injury; or the abnormal growths of tissue attending the irritation caused by animal parasites (galls) or by parasitic Fungi. In such cases the evidences of unusual activity on the part of the plant is shown in the morphological differences of the affected tissue. From an entirely different standpoint, that of the stimulus of the ordinary functions of the cells themselves, the work of Hauptfleisch ${ }^{1}$ affords interesting evidence. It appears from his observations that the movement of protoplasm is accelerated to an unwonted degree by injury to adjoining cells. In some plants, where under ordinary conditions no motion is observable (e.g. Elodea,

${ }^{1}$ Prings. Jahrb., Vol. xxiv, p. 190, 1892.

[Annals of Botany, Vol. XI. No. XLI. March, 1897.] 
Vallisneria), a marked streaming is seen after injury to neighbouring parts. But in relation to the subject of this paper, the effect of injury or other abnormal conditions on the functions of the plant as a whole is of particular interest. One of the best measures of increased activity of a plant is found in the intensity of the respiration; and this last has been determined, under a variety of irritating influences, to be temporarily considerably above the normal. For instance, under exposure to the vapour of chloroform or ether ${ }^{1}$, or to various gases in increased or diminished pressure ${ }^{2}$, and also after wounding ${ }^{3}$, the $\mathrm{CO}_{2}$-production rises markedly, and in the last-mentioned case at least subsequently falls to the normal.

It would seem then possible that all this extra work which is done under the stimulus of irritation, would necessitate a rise in the temperature of the affected parts. So it was suggested to the writer during his work on the respiration of injured plants, and so also had Pfeffer forecast the possibility of an increase in the temperature of plants through wounding 4 . To measure any rise of temperature on the wound-surface itself, it is of course quite impossible to employ a thermometer; instead of which a thermo-element, of which a description will be given later, was used. The results of the experiments attained by this method, and also on a large scale with a rough calorimeter, were sufficiently successful to warrant an account of them. The writer has again to thank Professor Pfeffer very much for his advice and criticism, and for the facilities afforded in the laboratory. In this place also the writer would express his obligation to Dr. Giessler, one of the assistants in the Botanical Institute at Leipzig, whose invaluable assistance, in the many operations which required two persons to carry out, contributed greatly to the success of the work.

1 Elfving, Öfversigt af Finska Vetensk-Soc. Förhandlingar, Vol. xxviii, I886.

${ }^{2}$ Johannsen, Untersuch. Tübingen, I. 686.-Stich. Flora, I89 I, p. I.

3 Richards, Respiration of Wounded Plants, Ann. of Bot., Vol. x, p. 532, I896.

- Studien zur Energetik der Pflanze, 1892, footnote 2, p. 201. 


\section{Heat by Wounded Plants.}

It should be understood at the outset that the results herein recorded should be taken as no more than a qualitative, and not as a quantitative, determination of the heat produced by injured plants. The object of the research was, in the first place, to establish the fact of a rise in temperature, if any, following the wounding of plant-tissues; and in the second place to determine the curve of the change of temperature. While all possible pains were taken to shut out, in so far as could be, any sources of error, the extreme accuracy of Rodewald's ${ }^{1}$ quantitative research was not so necessary.

As regards the apparatus and methods used, the thermoelectric element, in connexion with a mirror-galvanometer, was, as has already been hinted, mainly employed. The bolometric method was not used, since the former means proved sufficient for the purposes desired. A simple thermoelement similar to the form used by Dutrochet ${ }^{2}$, was the one selected. Such a single element is by no means so delicate as is a battery of twelve or thirty-six, such as Rodewald ${ }^{3}$ employed, but it proved sensitive enough, and was more advantageous, since the wound made by the element in the tissue under experimentation was reduced to a minimum. Such an element consists of two pieces of soft iron wire connected by a bow of German-silver wire, the points of contact being soldered by means of silver. The free ends of the iron wires are connected by means of binding screws to the wires from the galvanometer. The precise form of the points of this thermo-electric needle was only determined by experiment. At first sharp needle-points were tried, but proved ineffective for the purpose in hand, since they freed themselves too easily from the tissue in which they were imbedded. It was found that spatulate points, the idea of using which was obtained from Stahl ${ }^{4}$, were preferable, affording as they do a firmer hold in the plant, and also a larger

1 Pringsheim, Jahrb., Bände xviii, p. 263; xix, p. 221 ; xx, p. 261.

2 Annales des Sciences Naturelles Bot., Tome xiii, Série 3, p. 5 et seq.

3 Prings. Jahrb., Band xviii, p. 276 .

4 Stahl, Ann. du Jardin Bot. de Buitenzorg, Vol. xiii, p. I53. 
surface upon which the warmth may act. An element of this form, made out of iron wire of about I mm. and Germansilver wire of about $.75 \mathrm{~mm}$. in thickness, beaten out to form points about $6 \mathrm{~mm}$. in width at the widest point, was the one employed (see woodcut). Before use care was taken that it should be thoroughly coated with shellac to protect it from possible chemical action, and a large part of the element, where it would be likely to come in contact with the hands or other outside object, was covered with thick strips of cork cemented on with sealing-wax.

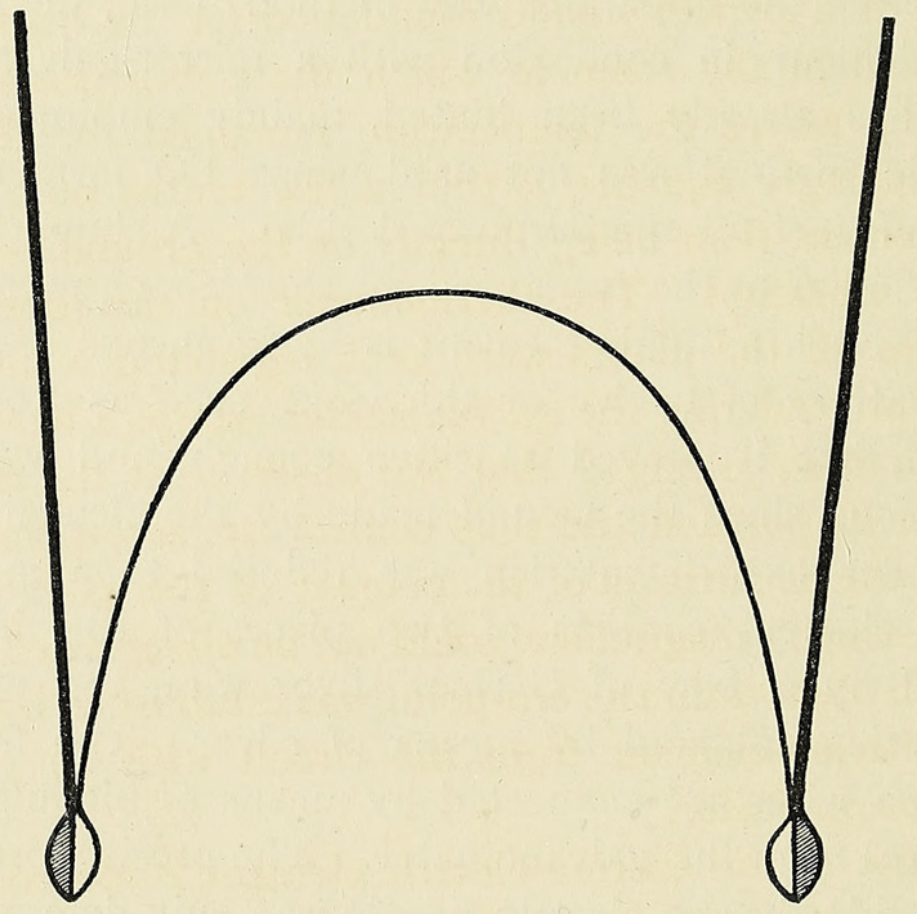

Woodcut I.

Diagram of the thermo-electric element employed; somewhat reduced. The shaded portion and the outer straight wires are of iron : the inner bow of Germansilver.

The galvanometer was one of the usual mirror-type, with scale and telescope, of which no especial description is necessary. The distance of the scale and telescope from the galvanometer itself was about 2.5 metres, but the telescope was sufficiently powerful to make each division of the scale appear as much as 3 millimetres across, so that a quarter or 
even a fifth of one division could be read with ease. There are many sources of error in the use of this instrument which require great precautions to exclude; all due care was taken to do so in so far as they might influence the work in hand. The galvanometer was naturally exceedingly sensitive to masses of iron; hence, so far as possible, all iron objects, particularly movable ones, were removed from the room. Another necessity is that the room in which the experiments are being carried on should be of constant or nearly constant temperature. This, together with a no less important condition, that of a perfectly solid foundation for the instruments, was realized in the room in which these experiments were performed; where the temperature remained for the most part exceedingly equable, within a few tenths of a degree, and the cement floor being directly on the ground, was quite free from vibration. The thermometer on the level of the table where all the plants were kept, registered a little over $24^{\circ} \mathrm{C}$. For rendering the galvanometer astatic, a bar-magnet was used and so arranged that the observer at the telescope could alter its position and thus control the zero-point. The change of the declination of the magnet of the galvanometer, due to the earth's magnetism, could not be disregarded; hence before each observation a zero-point was established by cutting out the thermo-element from the circuit with an ordinary mercury commutator.

In the use of the thermo-electric element Rodewald ${ }^{1}$ gives a number of precautions against errors, which were followed in so far as necessary in this work. The most important is the complete insulation of the element by means of an even, but not too thick, coat of hard shellac, which at the same time serves to protect the metal from the chemical action of the juices of the plant. A careful watch was kept to see that the shellac coating always remained intact, and very frequently the element was washed clean and re-lacked. The binding-screws which connect the iron wires of the element with the copper wires coming from the galvanometer were 
another source of trouble, since any disturbance of their constancy of temperature was followed by uncertain deflections of the galvanometer. Finally, however, they were encased in cork, which was found to thoroughly protect them from outside influences. As has already been said, a large portion of the element itself was also protected with cork and sealingwax. The above are the most weighty sources of error as regards the galvanometer and the thermo-electric element; in the actual experiments on living plants there are other precautions to be taken, of which more will be said later.

Frequent experiments established the fact that, with the scale used and at the distance at which it was placed from the mirror, one division had the value of $0.07^{\circ} \mathrm{C}$. It was found for the purpose desired that water of different temperatures, measured by standard normal thermometers, was as accurate as a more complicated apparatus with oil. Alcohol was also used, and the results obtained thereby agreed with the determinations made with water. In the experiments which will be found given at the end of this paper, one division of the galvanometer scale is taken then as the equivalent of $0.07^{\circ}$.

In the manipulation of the plants under experimentation, there are also many precautions to be taken against possible errors. In the first place the plants must be kept in an atmosphere saturated with moisture, both to prevent their withering and also to avoid changes of temperature due to evaporation from the cut surfaces of the injured plant. It is also necessary that they should have acquired the temperature of the warm room. A day or two was always allowed before the plants brought into the warm room were used. Another point which is exceedingly important is the placing of the thermo-needles in the objects. When the needle is thrust too much into that portion of the wound which gapes open, naturally little or no effect is observed; but when it is properly arranged near the base of the cut where the sides come together, the needle-point receives the full influence of both the cut surfaces. The latter method was always practised, 
with the exception of a few cases where the wound gaped so widely that it was impossible; under which circumstances the needle was stuck into the tissue directly behind the cut. Why this latter was not always done will be explained in a following paragraph. It is unfortunately impossible to obtain the necessary comparison of temperature between the injured and uninjured parts without inserting the needle into the latter as well as the former, and thereby wounding it slightly. The wound is slight, however, and as oxygen of the air can scarcely gain access around the needle thus introduced, the difference is not so important as it would seem. The error, too, if any, would tend to counteract the effect of the intended wound in the injured part, and hence in a qualitative determination such as this is not serious, especially since all the objects experimented with were treated in the same manner. In order to ensure absolute certainty that the injury purposely inflicted would not influence both needle-points, two objects were used (e.g. two potatoes) which are here always referred to as the uninjured and injured objects. It was found by repeated experiments that the various plants used, if they were of the same age and had presumably been kept under the same conditions, never varied appreciably in temperature in the uninjured condition. Without going further into the description of the manipulations gone through, it is sufficient to repeat that the various objects investigated were treated in as nearly as might be the same manner, and any errors arising thereby largely equalized ; which it will be appreciated is the most important desideratum in a purely qualitative determination. The writer recognizes, of course, that in a quantitative estimation of the amount of heat produced a much finer degree of accuracy would be required, such as Rodewald ${ }^{1}$ employed in his admirable researches.

As a control for the thermo-electric method, a series of experiments were carried on with a simple form of a calorimeter, by which the temperature-curve of a mass of plants could be determined. The results were of a confirmatory

\footnotetext{
1 Prings. Jahrb., l. c.
}

D 2 
nature. The apparatus consisted simply of two bell-glasses of about $1 \frac{1}{2}$ litres capacity, protected all around with a thick layer of cotton-wadding. The bell-glasses were also supplied with thermometers, which had previously been compared, and a small aperture, loosely stopped with a bit of cotton to prevent any rapid circulation, was provided for the admission of air. Inside the bell-glasses were also dishes of $\mathrm{KOH}$ for the absorption of the $\mathrm{CO}_{2}$ respired, and above these the plants were supported. After filling both of the bell-glasses, a day was allowed for them to become equalized in temperature. If readings taken in the evening and again the next morning both showed no difference between the two bellglasses, the plants in one of them were cut and then returned as quickly as possible. After this the difference between the temperatures in the two bell-glasses registered the effect of the injury, and readings taken from hour to hour showed the curve. It is unnecessary to say that these experiments were carried on in the room the temperature of which only on one or two occasions varied within a few tenths of a degree. The difference in the temperatures between some of the experiments is due to a difference in location of the bell-glasses. When on a higher level they were naturally somewhat warmer. For this reason the thermometers were carefully adjusted to the same level and never moved during the course of any one experiment. The amount of heat arising from the absorption of the $\mathrm{CO}_{2}$ by the $\mathrm{KOH}$ was not regarded, although of course it was greater in the injured than in the uninjured plants. But this is counterbalanced by the fact that the warmer bellglass must also lose more by radiation than the cooler. The apparatus was not intended to be more than approximately accurate, and the application of such corrections would not be worth while for the results required.

Although potatoes were used more than any other plant, a variety of others representing different sorts of tissue were experimented with. But potatoes were more convenient, and also had the great advantage of resisting the attacks of fungi better than anything else. The writer had also ex- 
perimented with them in regard to their respiration in the injured condition, and it was desirable to be able to compare the results of this with those of the previous investigation. The experiments with potatoes will, then, be first taken up.

It was never found that there was any difference in temperature between the cut surfaces and the uninjured potato immediately after injury; it was not until the second observation was made, usually some two hours after wounding, that any indication of increasing warmth in the injured plant was noticeable. The amount of increase was not found to be great at this time, being only about $0.07^{\circ} \mathrm{C}$, , but there is a steady increase after this. That there should be no sudden increase immediately after injury is to be expected. The cause of the large $\mathrm{CO}_{2}$-production at this time has been shown ${ }^{1}$ to be a physical one. The maximum temperature is not reached until some twenty-four hours after injury, a period corresponding to that of the respiration-intensity. As might be expected, there is some range of variation in the reaction of individual potatoes. Many things might lead to differences: as, for instance, a difference in the metabolic activity due to different age. It was usually found, however, that potatoes procured at the same time, i.e. which had presumably been gathered simultaneously and kept under the same conditions, gave pretty uniform results. The difference between old potatoes of the previous year and new ones was marked, as will be discussed a little later. One source of error which was to be guarded against was the use of unhealthy potatoes. It was found that sometimes potatoes with only a small rotten spot, which had no influence on the general temperature of the tuber, would further rot in the warm, moist atmosphere in which they were kept, until the decayed portion would affect the temperature of almost the whole potato. This is particularly insidious in that the increase of temperature from the rotting of the potato would simulate the rise following injury. Several series were discarded for this reason, and great care was taken to have none but healthy potatoes.

1 Richards, Respiration of Wounded Plants, Ann. Botany, Vol. x, p. 544, I896. 
After an experiment was completed, the tubers were cut in pieces and examined for any decayed spots. The surfaces of the wounds made in the potatoes never showed any signs of decay, presenting only the layer of corky tissue, quite dry and hard, over the surface.

The highest maximum ever noted was a temperaturedifference of the injured and uninjured potatoes of almost $0.4^{\circ} \mathrm{C}$. The return to the normal temperature after the maximum is slower than the ascending curve. There is a distinct drop in the temperature a few hours after the maximum, followed by a much slower decrease; until, by the fourth or fifth day after the injury was inflicted, no difference was to be determined with the apparatus used. The actual rise in temperature is not, of course, so very much ; but when the normal temperature of potatoes in relation to the surrounding medium is considered, it is not to be despised. Repeated experiments showed that at the temperature of the warm room, namely about $24^{\circ} \mathrm{C}$., old potatoes of the previous year showed a difference between the living and dead tissue of $0.16^{\circ} \mathrm{C}$. In new potatoes only recently out of the ground, the plus temperature under the same conditions of temperature and moisture was somewhat lower, viz. $0.13^{\circ} \mathrm{C}$. That the old potatoes have a higher temperature than the new ones is not remarkable, since the former are just emerging from their resting period, while the latter are just entering a period of quiescence where the metabolic activity is naturally low. A similar difference was found in the reaction to injury where the young potatoes did not respond so actively to the stimulation of the wound (compare Expts. 7, 9, and 10).

The relation which the rise of temperature bears to the increased respiratory activity after injury is naturally not to be directly estimated; since in this case the local warmth only is measured, while in the experiments on respiration it was the total effect which was determined. Approximately speaking, the temperature directly on the surface of a wound, or just below it, at the time of its maximum is about twice as great as the normal plus temperature of a living over 
a dead potato. Thus the temperature of a living uninjured potato being $0.17^{\circ} \mathrm{C}$. over that of the surrounding objects, the temperature on the cut surface of a wounded potato will at its maximum be from $0.20^{\circ} \mathrm{C}$ to $0.25^{\circ} \mathrm{C}$ higher than that of the uninjured plant. But it must be remembered that in these conclusions no allowance has been made either for the conduction of heat by the tissue of the potato itself or for radiation into the air, which must, of course, amount to something and must increase as the temperature of the tissue increases. In relation to this point and also the other regarding the comparison of the temperature with the respiration, it is exceedingly important to have some idea of how far the surrounding tissue of the potato is sympathetically affected in the increased warmth following injury.

It will be seen from Experiments II and I 2 that the influence of the wound does not extend very far back from the point of irritation. There is in most cases a very rapid falling off at a distance of only a few millimeters from the wound; and at a distance of two centimeters there is no perceptible difference. It is evident, then, that the real heat-producing processes which follow injury must be comparatively local, for the conduction of heat by the tissue of the potato naturally increases the distance at which a temperature-difference is distinguishable. In order to obtain a clearer understanding of this question, experiments were made to determine an approximate idea of the conductivity of potato-tissue for heat. Two potatoes in separate vessels were half buried in sand which was in one at the temperature of the air, namely $24 \cdot 2^{\circ} \mathrm{C}$.; while in the other it was kept during the time of the experiment nearly ten degrees higher. The needles were thrust into the two potatoes at a distance of $30 \mathrm{~mm}$. from the surface of the sand, and in fifteen minutes the galvanometer indicated an increase in temperature of the warmed potato amounting to $0.25^{\circ} \mathrm{C}$. By another experiment it was also found that two potatoes which showed by the galvanometer a difference in temperature of almost exactly $2^{\circ} \mathrm{C}$, took five and a half hours to become 
equalized, being kept the while at the temperature of the cooler of the two potatoes, namely $24 \cdot \mathrm{I}^{\circ} \mathrm{C}$. It is evident from these experiments that while the conductivity of the tissue for heat may not be very rapid in comparison with other bodies, it is not to be disregarded. Hence it is not too much to say that the actual heat-reaction of the wound itself appears less localized than it in reality is. It is, of course, impossible to separate these two factors, the actual warmth and the conducted warmth; but having found that, even including the latter, the tissue does not seem to show any increase in temperature beyond $20 \mathrm{~m}$. from the wound, it is safe to say that the actual wound-reaction is probably considerably inside of even this.

In the experiments with the two bell-glasses packed with cotton-wadding, the rise in temperature caused by a large mass of potatoes-500-600 grams-may be plotted on a curve which has much the same course as that determined by the thermoelectric method (see Woodcut 2, p. 63). Naturally it is not possible to compare the actual temperatures indicated by the two methods, for neither is quantitative. It is to be expected that the rise indicated by a large mass of potatoes should be higher than that obtained from a single tuber, and such is the case. That, as measured by this method, it should be proportionally greater is not to be looked for; as the indirect way of measuring the heat and the loss by radiation gives no accurate knowledge of the actual amount produced. The method is of value, however, in that in the two bell-glasses are two equal masses of potatoes under exactly similar conditions, except that in one they are injured while in the other they are normal. The rise to the maximum takes some twentyfour hours after the potatoes have been cut and returned to the bell-glass, and is about $0.9^{\circ} \mathrm{C}$. higher than the temperature given by the uninjured potatoes, the latter showing ordinarily a plus temperature of $0.4^{\circ} \mathrm{C}$. above that of the surrounding air. The return to zero of difference follows in the course of a few days. Such a method as this, if strictly followed out calorimetrically, would give results which could be better compared 
with the experiments made on respiration, since both methods deal with the total reaction on masses of tissue where the effect cannot be localized.

None of the other plants employed were investigated so thoroughly as potatoes, but enough to show that they too gave a distinct temperature-reaction after injury. Radishes were experimented with once or twice, and showed, in so far as the experiments could be carried, a reaction similar to that of potatoes. One experiment with the bell-glasses herein recorded (Expt. 23) remained trustworthy until after the maximum had been reached, but later it had to be abandoned as the radishes began to decay. The same trouble occurred with the other experiments, and for this reason radishes were no longer used. It was difficult at the time of year-June and July - when these experiments were made, to obtain carrots of sufficient size for use ; and they also have the disadvantage that the wounds when made gape open very widely after a few hours. Nevertheless a series was successfully finished, and showed very much the same results as those obtained with potatoes, although the temperature was lower (Expt. I5). This last fact may perhaps be explained by the circumstance of the gaping of the wound, which thereby allowed more loss of heat by radiation. The maximum comes at a somewhat later period, and the return to normal temperature somewhat slower than with potatoes, but this corresponds with the respiration-curve previously determined ${ }^{1}$. In the bellglasses the highest maximum yet mentioned was found, being $\mathrm{I} \cdot 35^{\circ} \mathrm{C}$. (Expt. 29), and as well the highest plus temperature of the normal tissue was indicated by both methods. By the thermo-electric method which gives the actual temperature of a single carrot, it was found under normal conditions to be $0.2^{\circ} \mathrm{C}$. (Expt. 16). It will be remembered that the normal respiration of carrots is very high, being about $15 \mathrm{mg}$. per hour. The swollen stem of the Kohl Rabi (Brassica oleracea var. gongylodes), and the fruit of the Cucumber, also gave

${ }^{1}$ Richards, Respiration of Wounded Plants, 1. c. Expts. 14, I5. 
temperature-curves with the thermo-electric apparatus (Expts. I $3,14,20$ ), but were not tried with the bell-glasses.

Leaves afforded an entirely different type of tissue. Ordinarily speaking these are not well adapted for the use of a thermo-element. The thick leaves of Aloe were experimented with in this way, although without success; but with onion-bulbs very interesting results, of which more will be said later, were obtained. With the bell-glasses ordinary leaves could be employed: experiments with those of Liriodendron and Diervilla gave very satisfactory results (Expts. $24,25)$. The maximum, as would be expected, was reached much more rapidly than with massive tissues. In four and a half hours the injured leaves, in the case of Liriodendron, were $0.75^{\circ} \mathrm{C}$. warmer than the uninjured, the latter showing an average temperature of about $0.4^{\circ} \mathrm{C}$. over that of the air. By the next day there was little difference, and that speedily diminished as the injured leaves died.

Of all the plants investigated onion-bulbs gave a far stronger reaction than any other. With the bell-glasses the average maximum of two experiments (Expts. 26 and 28 ) was $3.3^{\circ} \mathrm{C}$. This high temperature continued for some time; and it was not until the fifth day that it sank again to the normal plus temperature of about $0.5^{\circ} \mathrm{C}$. In one experiment (Expt. 27) it will be noticed that the maximum was much lower; but, at the same time, the temperature of these onions in the uninjured state was very much higher than in the other two experiments, being $\mathrm{I} \cdot 2^{\circ} \mathrm{C}$. above air-temperature. This accounts for the low maximum in the injured condition, and is probably to be explained by a difference in metabolic activity of the onions. It may be mentioned that the onions used in this experiment did not come from the same source as the others. With the thermo-element, however (Expts. 17 and I9), no remarkably high temperature was detected in the cut, or rather immediately behind it; since in onions the wounds gape so that it is impossible to stick the needle advantageously into the cut itself. This fact was puzzling until, by subsequent experiment, it was found that the whole 
onion is more or less, though somewhat irregularly, affected, and that at so great a distance as $45 \mathrm{~mm}$. from the wound a temperature of $0.17^{\circ} \mathrm{C}$. over that of the uninjured bulb was found, when it was only $0.28^{\circ} \mathrm{C}$. in the wound itself. It is, then, easy to believe that the small onions used in the bellglass experiments, and injured so severely as by quartering, should give a comparatively violent reaction.

From the above discussion of the results of the experiments it is evident that there is a distinct temperature-reaction, more or less variable, which manifests itself in plants after injury. This reaction is in fact a fever, if one may use the term, brought about by the increased vital activities of the wounded plants. In considering the significance of this 'wound-fever' one should also bear in mind the other phenomena which attend injury. Attention has already been called to these in the introduction to this paper. Of the greatest interest is the consideration of the relation which the increase in respiration bears to the rise in temperature. The respiration-curve was found to be at its highest, in potatoes for instance, about twentyfour hours after wounding; and it is at the same time that the maximum of the temperature-curve is indicated (Woodcut 2). In the same way, as has already been said, the phenomena go hand-in-hand in the case of leaves. The return of the temperature to the normal is, it is true, somewhat more rapid than that of the respiration, at least as far as was indicated by the method used; but after the fourth or fifth day it will be remembered that even the respiration is only very slightly above the normal ${ }^{1}$. Theoretically speaking, the rise in respiration, representing as it does an increase of chemical work in the tissues of the plant, demands a rise also of temperature, and it is interesting to find that, as a matter of fact, such is the case. Even granting that the respiratory processes are alone responsible for all the heat normally produced in a plant, the temperature could hardly be expected to increase correspondingly with the respiration. The writer would again call attention to the fact that by radiation and so

${ }^{1}$ See Richards, Respiration of Wounded Plants, l. c. 
forth an appreciable amount of the produced heat must be lost. It is, however, evident from the experiments in which the action of the air was prevented by the application of clay, that the phenomena, as regards both respiration ${ }^{2}$ and temperature (Expt. I $2 a$ ), are dependent on a supply of oxygen, since in these cases a marked diminution of the reaction was noticeable.

Of interest in this connexion are the results of Eriksson ${ }^{1}$, who has shown that the amount of heat produced during intra-molecular respiration is but a fraction-a tenth or thereabouts-of that which is formed when the same plants are respiring under normal conditions. It is not to be wondered at then that after injury, when the respiration and hence also the vital activities of plants are greatly stimulated, a rise of temperature should also be found.

But it is not a simple question of how much heat should be produced by the formation of a given amount of $\mathrm{CO}_{2}$, since it is living and not dead material which concerns us. There are, no doubt, many other changes which take place; the very fact which has already been shown ${ }^{2}$ that apparently more $\mathrm{O}_{2}$ is absorbed than is required for the amount of $\mathrm{CO}_{2}$ produced shows that oxidizing reactions may take place which, although they do not influence the amount of $\mathrm{CO}_{2}$ respired, might possibly give rise to temperature-changes. Yet in addition to these there are no doubt other phenomena attending injury which are not to be measured directly by their chemical effect. For instance, the acceleration of protoplasmic currents which Hauptfleisch ${ }^{3}$ has described, affords direct evidence of a disturbance of the normal condition of the cell-contents. It would be interesting to know from the point of view of time how these phenomena are related to those which may be determined in a physical or chemical manner: whether the accelerated protoplasmic movements precede - which perhaps is not impossible-or follow the other phenomena. From the observations of Hauptfleisch it would seem that,

1 Über Wärmebildung und intramoleculare Athmung der Pflanzen, Untersuch. Bot. Inst. zu Tübingen, Band I, p. Io5 et seq.

${ }^{2}$ See previous paper, 1. c. Table on p. $54^{8}$.

${ }^{3}$ Prings. Jahrb., 1. c. 
while the more rapid circulation is not general through the whole of an injured plant, it is propagated with a speed and to a distance which is not commensurate with the apparently local character of the heat-reaction, so that it would appear that the former perhaps precedes the latter.

That plants should, like animals, respond to the stimulus of an injury by an attempt to rally from it is not surprising; but that this rallying should be accompanied by somewhat the same symptoms is a matter of no little interest. It is true that the reaction is, absolutely, not so marked with a plant as with the higher animal; but when one considers that in the former case the cells and tissues are not so interdependent as in the latter, and that the whole scale of vitality is keyed to a lower pitch, this cannot be wondered at.

It should be remembered, however, that compared with the ordinary temperature of plants over the surrounding medium, the rise of temperature after injury is as great, if not greater, than in animals. Large or small the reaction is, however, sufficiently well marked to justify institution of a comparison between the rise in temperature following the injury of plants and the fever following the wounding of animals, both being due to the exerting of the vital forces of the organism to recover from the shock.

The main results of these experiments, as far as is to be judged from the objects experimented with, may be stated, in brief, as follows :-

I. That a certain rise in temperature of the adjacent tissue follows on the wounding of plants.

2. That this 'fever-reaction' runs a definite course, attaining its maximum some twenty-four hours after injury, so that a curve plotted from it corresponds in the main to that of the respiration-intensity under similar conditions (Woodcut 2).

3. That the maximum in all the plants investigated was between two and three times the ordinary plus temperature of the plant.

4. That in potatoes (i. e. massive tissues) the effect is local, but that in onion-bulbs (i. e. leaves) a much greater extent of tissue is sympathetically affected. 
A.

The experiments in this section were all made with a thermo-electric element attached to a galvanometer of the form and after the manner already described. In all cases the material used had been kept at least twenty-four hours in the warm room before being used. Hence no mention of this is made under the individual experiments. The readings of the galvanometer are given in divisions and fractions of divisions of the scale employed, and are corrected to the actual zero-point of galvanometer at the time the observations were made. I division of galvanometer scale $=0.07^{\circ} \mathrm{C}$.

\section{EXPERIMENT 1.}

Two potatoes $7-8 \mathrm{~cm}$. long. In uninjured condition show equal temperature. One cut at $4.00 \mathrm{p} . \mathrm{m}$., the other left uninjured.

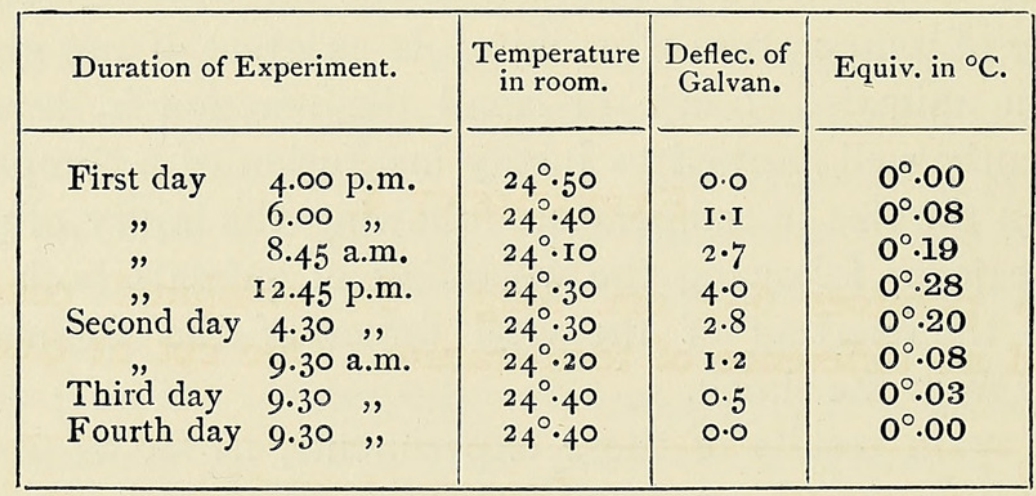

\section{EXPERIMENT 2.}

Two potatoes $7-8 \mathrm{~cm}$. long. No difference in temperature in uninjured state. One cut at 4.00 p.m.

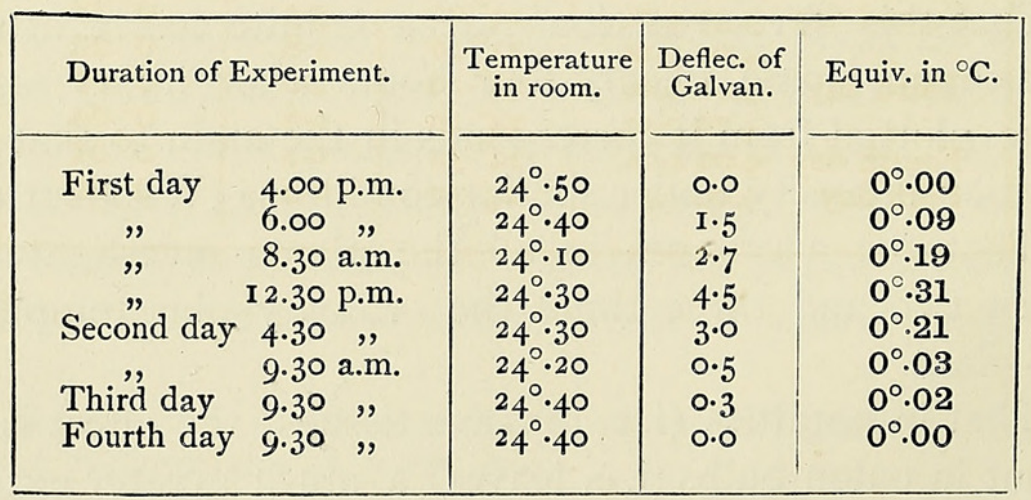




\section{EXPERIMENT 3.}

Two potatoes $8-9 \mathrm{~cm}$. long. In uninjured condition showed no difference of temperature. One cut at 8.45 a.m.

\begin{tabular}{|c|c|c|c|c|}
\hline Duration of $]$ & Experiment. & $\begin{array}{l}\text { Temperature } \\
\text { in room. }\end{array}$ & Deflec. of & Equiv. in ${ }^{\circ} \mathrm{C}$. \\
\hline $\begin{array}{l}\text { First day } \\
\text { ", } \\
\text { Second day } \\
\text { Third day } \\
\text { Fourth day }\end{array}$ & $\begin{array}{l}8.45 \text { a.m. } \\
\text { I } 2.00 \text { noon } \\
5.00 \text { p.m. } \\
9.00 \text { a.m. } \\
4.45 \text { p.m. } \\
9.30 \text { a.m. } \\
9.30,\end{array}$ & $\begin{array}{l}24^{\circ} \cdot 10 \\
24^{\circ} \cdot 20 \\
24^{\circ} \cdot 25 \\
24^{\circ} \cdot 10 \\
24^{\circ} \cdot 10 \\
24^{\circ} \cdot 30 \\
24^{\circ} \cdot 30\end{array}$ & $\begin{array}{l}0.0 \\
1 \cdot 0 \\
2 \cdot 0 \\
3 \cdot 0 \\
2 \cdot 2 \\
0.8 \\
0.0\end{array}$ & $\begin{array}{l}0^{\circ} .00 \\
0^{\circ} .07 \\
0^{\circ} .14 \\
0^{\circ} .21 \\
0^{\circ} .15 \\
0^{\circ} .06 \\
0^{\circ} .00\end{array}$ \\
\hline
\end{tabular}

\section{EXPERIMENT 4.}

Two potatoes $6-7 \mathrm{~cm}$. long. In uninjured condition showed no difference of temperature. One cut at 9.00 a.m.

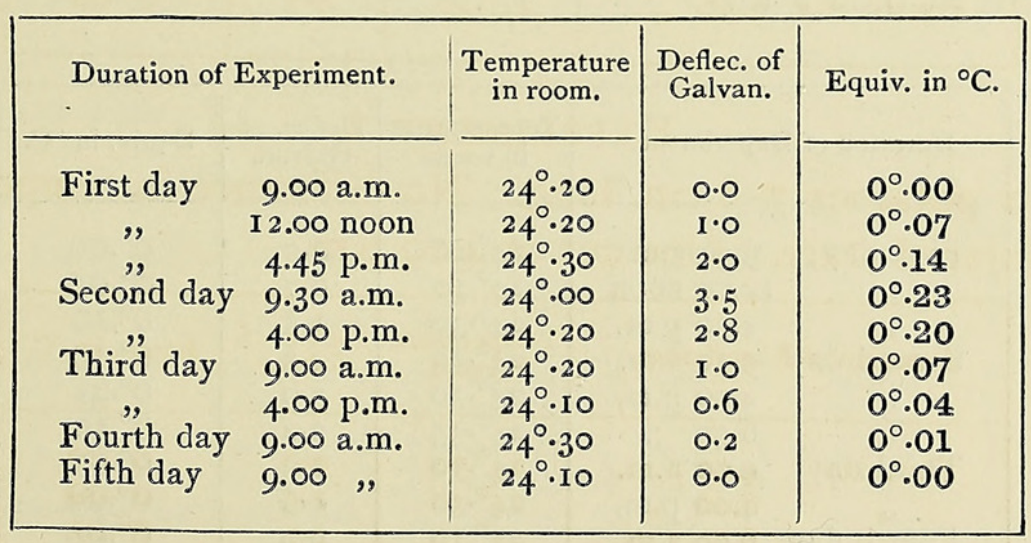




\section{EXPERIMENT 5.}

Two potatoes $8 \mathrm{~cm}$. long. Uninjured equal in temperature. One cut at 9.30 a.m.

\begin{tabular}{|c|c|c|c|c|}
\hline \multicolumn{2}{|c|}{ Duration of Experiment. } & $\begin{array}{l}\text { Temperature } \\
\text { in room. }\end{array}$ & $\begin{array}{l}\text { Deflec. of } \\
\text { Galvan. }\end{array}$ & Equiv. in ${ }^{\circ} \mathrm{C}$. \\
\hline $\begin{array}{l}\text { First day } \\
\text { ", } \\
\text { Second day } \\
\text { Third day } \\
\text { Fourth day }\end{array}$ & $\begin{array}{l}9.30 \text { a.m. } \\
\text { I 2.I } 5 \text { p.m. } \\
3.00 " \\
4.50 \text { ", } \\
9.30 \text { a.m. } \\
4.00 \text { p.m. } \\
9.00 \text { a.m. } \\
4.15 \text { p.m. } \\
9.00 \text { a.m. }\end{array}$ & $\begin{array}{l}24^{\circ} \cdot 20 \\
24^{\circ} \cdot 20 \\
24^{\circ} \cdot 25 \\
24^{\circ} \cdot 30 \\
24^{\circ} \cdot 00 \\
24^{\circ} \cdot 00 \\
24^{\circ} \cdot 20 \\
24^{\circ} \cdot 30 \\
24^{\circ} \cdot 10\end{array}$ & $\begin{array}{l}0.0 \\
0.8 \\
1.6 \\
3.0 \\
3.8 \\
2.5 \\
0.6 \\
0.5 \\
0.3\end{array}$ & $\begin{array}{l}0^{\circ} .00 \\
0^{\circ} .06 \\
0^{\circ} .11 \\
0^{\circ} .21 \\
0^{\circ} .27 \\
0^{\circ} \cdot 17 \\
0^{\circ} .04 \\
0^{\circ} .03 \\
0^{\circ} .02\end{array}$ \\
\hline
\end{tabular}

\section{EXPERIMENT 6.}

Two potatoes $7 \mathrm{~cm}$. long. Uninjured equal in temperature. One cut at 9.00 a.m.

\begin{tabular}{|c|c|c|c|c|}
\hline \multicolumn{2}{|c|}{ Duration of Experiment. } & $\begin{array}{l}\text { Temperature } \\
\text { in room. }\end{array}$ & $\begin{array}{l}\text { Deflec. of } \\
\text { Galvan. }\end{array}$ & Equiv. in ${ }^{\circ} \mathrm{C}$. \\
\hline $\begin{array}{c}\text { First day } \\
\text { ", } \\
\text { Second day } \\
\text {," } \\
\text { Third day } \\
\text { Fourth day }\end{array}$ & $\begin{array}{l}9.30 \text { a.m. } \\
\text { I } 2.00 \text { noon } \\
4.30 \text { p.m. } \\
9.30 \text { a.m. } \\
4.00 \text { p.m. } \\
6.30 \text { ", } \\
9.00 \text { a.m. } \\
4.00 \text { p.m. } \\
9.00 \text { a.m. }\end{array}$ & $\begin{array}{l}24^{\circ} \cdot 10 \\
24^{\circ} \cdot 10 \\
24^{\circ} \cdot 30 \\
24^{\circ} \cdot 20 \\
24^{\circ} \cdot 30 \\
24^{\circ} \cdot 35 \\
24^{\circ} \cdot 20 \\
24^{\circ} \cdot 30 \\
24^{\circ} \cdot 10\end{array}$ & $\begin{array}{l}0.0 \\
0.7 \\
I \cdot 5 \\
4 \cdot 3 \\
3 \cdot 0 \\
2 \cdot 2 \\
I \cdot 0 \\
0.6 \\
0.0\end{array}$ & $\begin{array}{l}0^{\circ} \cdot 00 \\
0^{\circ} \cdot 05 \\
0^{\circ} \cdot 10 \\
0^{\circ} \cdot 30 \\
0^{\circ} \cdot 21 \\
0^{\circ} \cdot 15 \\
0^{\circ} \cdot 07 \\
0^{\circ} .04 \\
0^{\circ} .00\end{array}$ \\
\hline
\end{tabular}




\section{EXPERIMENT $\%$}

Two potatoes $10 \mathrm{~cm}$. long. These potatoes were of another lot than the ones previously tried. In uninjured condition no difference in temperature. One cut at 9.00 a.m.

\begin{tabular}{|c|c|c|c|c|}
\hline Duration of & Experiment. & $\begin{array}{l}\text { Temperature } \\
\text { in room. }\end{array}$ & $\begin{array}{l}\text { Deflec. of } \\
\text { Galvan. }\end{array}$ & Equiv. in ${ }^{\circ} \mathrm{C}$. \\
\hline $\begin{array}{c}\text { First day } \\
\text {," } \\
\text { Second day } \\
\text {," } \\
\text { Third day } \\
\text {," } \\
\text { Fourth day } \\
\text { Fifth day }\end{array}$ & $\begin{array}{l}9.00 \text { a.m. } \\
\text { I } 1.30 \text {," } \\
3.45 \text { p.m. } \\
6.00, " \\
9.00 \text { a.m. } \\
\text { I } 1.00,, \\
4.00 \text { p.m. } \\
9.00 \text { a.m. } \\
\text { I } 2.00 \text { noon } \\
4.00 \text { p.m. } \\
\text { I } 2.00 \text { noon } \\
\text { I } 2.00, "\end{array}$ & $\begin{array}{l}24^{\circ} \cdot 40 \\
24^{\circ} \cdot 50 \\
24^{\circ} \cdot 30 \\
24^{\circ} \cdot 30 \\
24^{\circ} \cdot 10 \\
24^{\circ} \cdot 20 \\
24^{\circ} \cdot 30 \\
24^{\circ} \cdot 30 \\
24^{\circ} \cdot 40 \\
24^{\circ} \cdot 40 \\
24^{\circ} \cdot 10 \\
24^{\circ} \cdot 20\end{array}$ & $\begin{array}{l}0.0 \\
I \cdot 5 \\
2 \cdot 5 \\
3 \cdot 3 \\
4 \cdot 5 \\
5 \cdot 5 \\
3 \cdot 7 \\
2 \cdot 7 \\
2.0 \\
I \cdot 5 \\
0.8 \\
0.3\end{array}$ & $\begin{array}{l}0^{\circ} \cdot 10 \\
0^{\circ} \cdot 17 \\
0^{\circ} \cdot 23 \\
0^{\circ} \cdot 31 \\
0^{\circ} \cdot 38 \\
0^{\circ} \cdot 26 \\
0^{\circ} \cdot 18 \\
0^{\circ} \cdot 14 \\
0^{\circ} \cdot 10 \\
0^{\circ} \cdot 06 \\
0^{\circ} \cdot 02\end{array}$ \\
\hline
\end{tabular}

\section{EXPERIMENT 8.}

Two potatoes $9 \mathrm{~cm}$. long; of same lot as Experiment 7 . No difference in temperature in uninjured condition. One cut at 9.00 a.m.

\begin{tabular}{|c|c|c|c|c|}
\hline \multicolumn{2}{|c|}{ Duration of Experiment. } & $\begin{array}{l}\text { Temperature } \\
\text { in room. }\end{array}$ & $\begin{array}{l}\text { Deflec. of } \\
\text { Galvan. }\end{array}$ & Equiv. in ${ }^{\circ} \mathrm{C}$. \\
\hline $\begin{array}{l}\text { First day } \\
\text { ", } \\
\text { Second day } \\
\text {," } \\
\text { Third day } \\
\text { Fourth day } \\
\text { Fifth day }\end{array}$ & 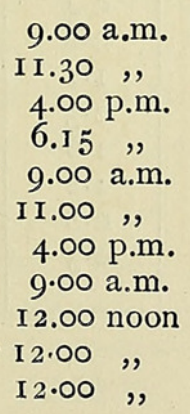 & $\begin{array}{l}24^{\circ} \cdot 40 \\
24^{\circ} \cdot 50 \\
24^{\circ} \cdot 30 \\
24^{\circ} \cdot 30 \\
24^{\circ} \cdot 10 \\
24^{\circ} \cdot 20 \\
24^{\circ} \cdot 30 \\
24^{\circ} \cdot 30 \\
24^{\circ} \cdot 40 \\
24^{\circ} \cdot 40 \\
24^{\circ} \cdot 20\end{array}$ & $\begin{array}{l}0 \cdot 0 \\
I \cdot 5 \\
2 \cdot 3 \\
3 \cdot 3 \\
4 \cdot 0 \\
5 \cdot 3 \\
4 \cdot 2 \\
3 \cdot 0 \\
2 \cdot 3 \\
I \cdot 3 \\
0.4\end{array}$ & $\begin{array}{l}0^{\circ} \cdot 00 \\
0^{\circ} \cdot 10 \\
0^{\circ} \cdot 16 \\
0^{\circ} \cdot 23 \\
0^{\circ} \cdot 28 \\
0^{\circ} \cdot 37 \\
0^{\circ} \cdot 29 \\
0^{\circ} .21 \\
0^{\circ} \cdot 16 \\
0^{\circ} \cdot 10 \\
0^{\circ} \cdot 03\end{array}$ \\
\hline
\end{tabular}




\section{EXPERIMENT 9.}

Two potatoes $5^{-6} \mathrm{~cm}$. long. These were young potatoes of the new year's crop, unlike the one previously experimented with. In the uninjured condition they showed no difference in temperature. One cut at $9.00 \mathrm{a} . \mathrm{m}$.

\begin{tabular}{|c|c|c|c|c|}
\hline \multicolumn{2}{|c|}{ Duration of Experiment. } & Temperature & $\begin{array}{l}\text { Deflec. of } \\
\text { Galvan. }\end{array}$ & Equiv. in ${ }^{\circ} \mathrm{C}$. \\
\hline First day & 9.00 a.m. & $24^{\circ} \cdot 30$ & 0.0 & $0^{\circ} .00$ \\
\hline & II.00, , & $24^{\circ} \cdot 30$ & 0.6 & $0^{\circ} .04$ \\
\hline & 3.00 p.m. & $24^{\circ} \cdot 10$ & I. 6 & $0^{\circ} .11$ \\
\hline Second day & 9.30 a.m. & $24^{\circ} \cdot 20$ & 2.0 & $0^{\circ} .14$ \\
\hline & I. 00 p.m. & $24^{\circ} \cdot 50$ & I. 8 & $0^{\circ} .13$ \\
\hline Third day & I 2.00 noon & $24^{\circ} \cdot 30$ & I. 8 & $0^{\circ} .13$ \\
\hline & 3.30 p.m. & $24^{\circ} \cdot 30$ & I. 5 & $0^{\circ} \cdot 10$ \\
\hline Fourth day & 4.00 & $24^{\circ} \cdot 10$ & 0.0 & $0^{\circ} .00$ \\
\hline
\end{tabular}

\section{EXPERIMENT 10.}

Two potatoes 5-6 cm. long. Same lot as used in Experiment 9 . No difference in temperature in uninjured condition. One cut at 9.30 a.m.

\begin{tabular}{|c|c|c|c|c|}
\hline \multicolumn{2}{|c|}{ Duration of Experiment. } & $\begin{array}{l}\text { Temperature } \\
\text { in room. }\end{array}$ & $\begin{array}{l}\text { Deflec. of } \\
\text { Galvan. }\end{array}$ & Equiv. in ${ }^{\circ} \mathrm{C}$. \\
\hline First day & 9.30 a.m. & $24^{\circ} \cdot 30$ & 0.0 & $0^{\circ} .00$ \\
\hline , & II.I 5, & $24^{\circ} \cdot 3^{\circ}$ & 0.4 & $0^{\circ} .03$ \\
\hline ", & 3.I 5 p.m. & $24^{\circ} \cdot$. 0 & $0.8^{+}$ & $0^{\circ} .06$ \\
\hline , & 6.00, & $24^{\circ} \cdot 20$ & I. 2 & $0^{\circ} .08$ \\
\hline Second day & $9.30 \mathrm{a} . \mathrm{m}$. & $24^{\circ} \cdot 20$ & $2 \cdot 3$ & $0^{\circ} .16$ \\
\hline & 3.00 p.m. & $24^{\circ} \cdot 50$ & I. 6 & $0^{\circ} .11$ \\
\hline Third day & $9.00 \mathrm{a} . \mathrm{m}$. & $24^{\circ} \cdot 30$ & I. 2 & $0^{\circ} .08$ \\
\hline & 3.30 p.m. & $24^{\circ} \cdot 20$ & 0.8 & $0^{\circ} .06$ \\
\hline Fourth day & $4.00 "$ & $24^{\circ} \cdot 10$ & 0.3 & $0^{\circ} .02$ \\
\hline
\end{tabular}




\section{EXPERIMENT 11.}

To determine the distance at which the increase of temperature may be noticed. Two potatoes, one of which was cut in the usual way, were kept until the injured one had attained its maximum temperature.

\begin{tabular}{|c|c|c|c|}
\hline & $\begin{array}{l}\text { Deflec. of } \\
\text { Galvan. }\end{array}$ & $\begin{array}{l}\text { Equiv. in } \\
\text { Celsius }\end{array}$ & $\begin{array}{c}\text { Tempera- } \\
\text { ture } \\
\text { in room. }\end{array}$ \\
\hline In wound & $\begin{array}{l}3.0 \\
I .8\end{array}$ & 0.21 & $24^{\circ} \cdot 30$ \\
\hline $\begin{array}{l}5 \mathrm{~mm} \text {. distant } \\
\text { I I } \mathrm{mm} \text {. }\end{array}$ & $\begin{array}{l}\text { I. } 8 \\
\text { I. }\end{array}$ & $\begin{array}{l}0.11 \\
0.07\end{array}$ & \\
\hline I $5 \mathrm{~mm}$. " & 0.7 & 0.05 & \\
\hline $20 \mathrm{~mm}$., , & 0.0 & 0.00 & \\
\hline
\end{tabular}

\section{EXPERIMENT 12.}

For the same purpose as Experiment 11. Potatoes treated in the same way.

\begin{tabular}{|c|c|c|c|}
\hline & $\begin{array}{l}\text { Deflec. of } \\
\text { Galvan. }\end{array}$ & $\begin{array}{l}\text { Equiv. in } \\
\text { Celsius }\end{array}$ & $\begin{array}{l}\text { Tempera- } \\
\text { ture } \\
\text { in room. }\end{array}$ \\
\hline In wound & $3 \cdot 0$ & 0.21 & $24^{\circ} \cdot 30$ \\
\hline $0.5 \mathrm{~mm}$. distant & $2 \cdot 2$ & 0.15 & \\
\hline $3.5 \mathrm{~mm}$. & $2 \cdot 0$ & 0.14 & \\
\hline $8.0 \mathrm{~mm}$. & I. 8 & 0.13 & \\
\hline I.० mm. , & I. 6 & 0.11 & \\
\hline $\mathrm{r} \cdot 3 \mathrm{~mm} . \quad$, & 1.0 & 0.07 & \\
\hline I.7 mm. " & 0.5 & 0.03 & \\
\hline
\end{tabular}

\section{EXPERIMENT $12 \alpha$.}

To determine the effect of exclusion of air from the wounded parts. Two potatoes, one of which was cut and the cuts immediately pressed together and covered with clay. No deflection of the galvanometer was observed immediately subsequent to injury. After standing twenty-four hours clay removed and determination made.

\begin{tabular}{|cc|c|c|c|}
\hline & $\begin{array}{c}\text { Temperature } \\
\text { in room. }\end{array}$ & $\begin{array}{c}\text { Deflec. of } \\
\text { Galvan. }\end{array}$ & $\begin{array}{c}\text { Equiv. } \\
\text { in }{ }^{\circ} \mathrm{C} .\end{array}$ \\
\hline July 20. & 9.00 a.m. & 24.30 & I.0 & 0.07 \\
,, & I 2.00 noon & $24 \cdot 35$ & I.7 & 0.12 \\
,, & 5.00 p.m. & 24.30 & 2.4 & 0.17 \\
\hline
\end{tabular}

E 2 


\section{EXPERIMENT 13.}

Two specimens of kohl-rabi (Brassica oleracea var. gongylodes) 7-8 cm. diameter. Leaves had been removed, but wounds entirely healed. In uninjured condition showed no difference in temperature. One cut at $9.00 \mathrm{a} . \mathrm{m}$.

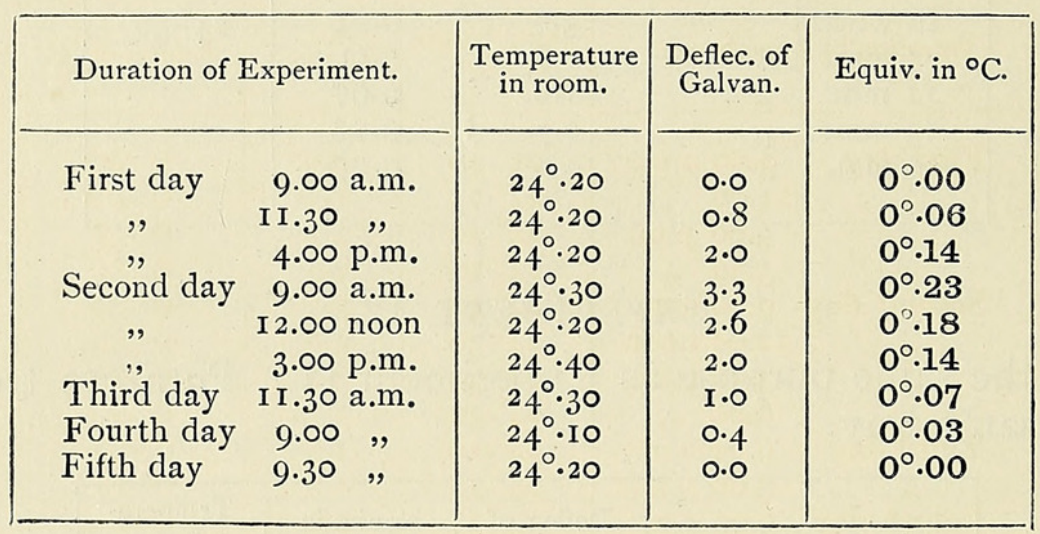

\section{EXPERIMENT 14.}

Two specimens of kohl-rabi (Brassica oleracea var. gongylodes) $8 \mathrm{~cm}$. in diameter. As above. Uninjured, no difference in temperature. One cut at 9.00 a.m.

\begin{tabular}{|c|c|c|c|c|}
\hline \multicolumn{2}{|c|}{ Duration of Experiment. } & $\begin{array}{l}\text { Temperature } \\
\text { in room. }\end{array}$ & $\begin{array}{l}\text { Deflec. of } \\
\text { Galvan. }\end{array}$ & Equiv. in ${ }^{\circ} \mathrm{C}$. \\
\hline $\begin{array}{l}\text { First day } \\
\text { ", } \\
\text { Second day } \\
\text { Third day } \\
\text { Fourth day } \\
\text { Fifth day }\end{array}$ & $\begin{array}{l}9.00 \text { a.m. } \\
\text { I I.45 ", } \\
4 . \mathrm{I} 5 \text { p.m. } \\
9.00 \text { a.m. } \\
3.00 \text { p.m. } \\
9.00 \text { a.m. } \\
\text { I I.30 ", } \\
9.00 ", \\
9.30 ",\end{array}$ & $\begin{array}{l}24^{\circ} \cdot 20 \\
24^{\circ} \cdot 20 \\
24^{\circ} \cdot 20 \\
24^{\circ} \cdot 30 \\
24^{\circ} \cdot 40 \\
24^{\circ} \cdot 35 \\
24^{\circ} \cdot 30 \\
24^{\circ} \cdot 10 \\
24^{\circ} \cdot 20\end{array}$ & $\begin{array}{l}0.0 \\
I \cdot 3 \\
2.8 \\
3 \cdot 5 \\
3.0 \\
I .8 \\
I \cdot 3 \\
0.2 \\
0.0\end{array}$ & $\begin{array}{l}0^{\circ} .00 \\
0^{\circ} .09 \\
0^{\circ} .20 \\
0^{\circ} .24 \\
0^{\circ} .21 \\
0^{\circ} .12 \\
0^{\circ} .09 \\
0^{\circ} .01 \\
0^{\circ} .00\end{array}$ \\
\hline
\end{tabular}




\section{EXPERIMENT 15.}

Two carrots (Daucus Carota) about $15 \mathrm{~cm}$. long. Had been thirty-six hours in warm room, and showed no difference of temperature before injury. One cut at $9.00 \mathrm{a} . \mathrm{m}$.

\begin{tabular}{|c|c|c|c|c|}
\hline \multicolumn{2}{|c|}{ Duration of Experiment. } & $\begin{array}{l}\text { Temperature } \\
\text { in room. }\end{array}$ & $\begin{array}{l}\text { Deflec. of } \\
\text { Galvan. }\end{array}$ & Equiv. in ${ }^{\circ} \mathrm{C}$. \\
\hline First day & 9.00 a.m. & $24^{\circ} \cdot 20$ & 0.0 & $0^{\circ} .00$ \\
\hline , & II.00 & $24^{\circ} \cdot 25$ & $\mathrm{I} \cdot 3$ & $0^{\circ} .09$ \\
\hline 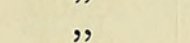 & 3.00 p.m. & $24^{\circ} \cdot 20$ & $2 \cdot 5$ & $0^{\circ} \cdot 17$ \\
\hline & 5.30, & $24^{\circ} \cdot 10$ & 2.8 & $0^{\circ} \cdot 20$ \\
\hline Second day & 9.00 a.m. & $24^{\circ} \cdot 40$ & $3 \cdot 3$ & $0^{\circ} \cdot 23$ \\
\hline , & I 2.00 noon & $24^{\circ} \cdot 30$ & $3 \cdot 6$ & $0^{\circ} \cdot 25$ \\
\hline & 3.30 p.m. & $24^{\circ} \cdot 30$ & $3 \cdot 3$ & $0^{\circ} \cdot 23$ \\
\hline & 6.00, & $24^{\circ} \cdot 30$ & $3 \cdot 3$ & $0^{\circ} \cdot 23$ \\
\hline Third day & 9.00 a.m. & $24^{\circ} \cdot 10$ & I. 8 & $0^{\circ} \cdot 13$ \\
\hline & 3.00 p.m. & $24^{\circ} \cdot 20$ & I. 6 & $0^{\circ} \cdot 11$ \\
\hline Fourth day & 9.00 a.m. & $24^{\circ} \cdot 20$ & 0.6 & $0^{\circ} \cdot 04$ \\
\hline Fifth day & 9.00, & $24^{\circ} \cdot 30$ & 0.2 & $0^{\circ} \cdot 01$ \\
\hline
\end{tabular}

\section{EXPERIMENT 16.}

Comparison of living and dead tissues of various plants. The dead plants were killed with boiling water. The temperature given is the natural + temperature of the plants.

\begin{tabular}{|c|c|c|}
\hline & $\begin{array}{l}\text { Deflec. of } \\
\text { Galvan. }\end{array}$ & Equiv. in ${ }^{\circ} \mathrm{C}$. \\
\hline Potatoes (old) $a$ & $2 \cdot 3$ & 0.16 \\
\hline , & $2 \cdot 5$ & 0.17 \\
\hline Potatoes (new) $c$ & $2 \cdot 0$ & 0.14 \\
\hline,$\quad d$ & 2.0 & 0.14 \\
\hline Onion & $\mathrm{I} \cdot 7$ & 0.12 \\
\hline Carrot & 2.8 & 0.20 \\
\hline
\end{tabular}




\section{EXPERIMENT 17.}

Two onions (Allium Cepa) diameter about $6 \mathrm{~cm}$. In warm room three days before using. One cut at $10.00 \mathrm{a} . \mathrm{m}$. The wounds gape so that the needle was always inserted a little behind the cut surface.

\begin{tabular}{|c|c|c|c|c|}
\hline Duration of & Experiment. & $\begin{array}{l}\text { Temperature } \\
\text { in room. }\end{array}$ & $\begin{array}{l}\text { Deflec. of } \\
\text { Galvan. }\end{array}$ & Equiv. in ${ }^{\circ} \mathrm{C}$. \\
\hline $\begin{array}{c}\text { First day } \\
\text { ", } \\
\text { Second day } \\
\text {," } \\
\text { Third day } \\
\text { ", } \\
\text { Fourth day } \\
\text { Fifth" day } \\
\text { ", }\end{array}$ & $\begin{array}{c}\text { I0.00 a.m. } \\
\text { I } 2.00 \text { noon } \\
3.00 \text { p.m. } \\
6.00 \text {, } \\
9.00 \text { a.m. } \\
\text { I } 2.00 \text { noon } \\
5.00 \text { p.m. } \\
6.00,, \\
9.00 \text { a.m. } \\
\text { I } 2.00 \text { noon } \\
2.00 \text { p.m. } \\
9.00 \text { a.m. } \\
5.00 \text { p.m. } \\
9.00 \text { a.m. } \\
5.00 \text { p.m. }\end{array}$ & $\begin{array}{l}24^{\circ} \cdot 20 \\
24^{\circ} \cdot 20 \\
24^{\circ} \cdot 30 \\
24^{\circ} \cdot 15 \\
24^{\circ} \cdot 10 \\
24^{\circ} \cdot 00 \\
24^{\circ} \cdot 15 \\
24^{\circ} \cdot 20 \\
24^{\circ} \cdot 40 \\
24^{\circ} \cdot 50 \\
24^{\circ} \cdot 40 \\
24^{\circ} \cdot 50 \\
24^{\circ} \cdot 30 \\
24^{\circ} \cdot 30 \\
24^{\circ} \cdot 40\end{array}$ & $\begin{array}{l}0.0 \\
I \cdot 6 \\
3 \cdot 2 \\
4 \cdot 0 \\
4 \cdot 0 \\
4 \cdot 3 \\
4 \cdot 0 \\
3 \cdot 0 \\
2 \cdot 3 \\
2 \cdot 0 \\
I \cdot 6 \\
I \cdot 0 \\
I \cdot 0 \\
0.6 \\
0 \cdot 3\end{array}$ & $\begin{array}{l}0^{\circ} .00 \\
0^{\circ} .11 \\
0^{\circ} .22 \\
0^{\circ} .28 \\
0^{\circ} .28 \\
0^{\circ} .30 \\
0^{\circ} .28 \\
0^{\circ} .21 \\
0^{\circ} .16 \\
0^{\circ} .14 \\
0^{\circ} .11 \\
0^{\circ} .07 \\
0^{\circ} .07 \\
0^{\circ} .04 \\
0^{\circ} .02\end{array}$ \\
\hline
\end{tabular}

\section{EXPERIMENT 18.}

Showing that the whole tissue of the onion is sympathetically affected. Two onions, one of which was wounded by cutting. Allowed to remain twenty-four hours until maximum reached. Temperature, $24^{\circ} \cdot 40$.

\begin{tabular}{|c|c|c|}
\hline $\begin{array}{c}\text { Distance from. } \\
\text { wound. }\end{array}$ & Deflec. of Galvan. & Equiv. in ${ }^{\circ} \mathrm{C}$. \\
\hline I mm. & 4.0 & 0.28 \\
$2.4 \mathrm{~mm}$. & 3.0 & 0.21 \\
$3.5 \mathrm{~mm}$. & 3.0 & 0.21 \\
$10.0 \mathrm{~mm}$. & 3.3 & 0.23 \\
$16.0 \mathrm{~mm}$. & 3.0 & 0.21 \\
$45.0 \mathrm{~mm}$. & 2.5 & 0.17 \\
\hline
\end{tabular}




\section{EXPERIMENT 19.}

Two onions (Allium Cepa) about $5 \mathrm{~cm}$. in diameter. As in Experiment I 7. One cut at 9.30 a.m.

\begin{tabular}{|c|c|c|c|c|}
\hline \multicolumn{2}{|c|}{ Duration of Experiment. } & $\begin{array}{l}\text { Temperature } \\
\text { in room. }\end{array}$ & $\begin{array}{l}\text { Deflec. of } \\
\text { Galvan. }\end{array}$ & Equiv. in ${ }^{\circ} \mathrm{C}$ \\
\hline First day & $9.30 \mathrm{a} . \mathrm{m}$. & $24^{\circ} \cdot 20$ & 0.0 & $0^{\circ} .00$ \\
\hline \multirow{3}{*}{ ", } & I 2.00 noon & $24^{\circ} \cdot 20$ & I. 5 & $0^{\circ} \cdot 10$ \\
\hline & 3.00 p.m. & $24^{\circ} \cdot 30$ & 3.5 & $0^{\circ} .24$ \\
\hline & 6.00, & $24^{\circ} \cdot \mathrm{I} 5$ & 4.0 & $0^{\circ} .28$ \\
\hline Second day & 9.00 a.m. & $24^{\circ} \cdot 10$ & $4 \cdot 0$ & $0^{\circ} .28$ \\
\hline \multirow{2}{*}{, } & I 2.00 noon & $24^{\circ} \cdot 10$ & $4 \cdot 0$ & $0^{\circ} .28$ \\
\hline & 3.00 p.m. & $24^{\circ} \cdot 00$ & 3.8 & $0^{\circ} .27$ \\
\hline \multirow{3}{*}{$\begin{array}{c}\text { Third day } \\
\text {," }\end{array}$} & 6.00, & $24^{\circ} .00$ & $3 \cdot 3$ & $0^{\circ} .23$ \\
\hline & $9.00 \mathrm{a} . \mathrm{m}$ & $24^{\circ} \cdot 40$ & 2.6 & $0^{\circ} .18$ \\
\hline & I 2.00 noon & $24^{\circ} \cdot 5^{\circ}$ & $2 \cdot 5$ & $0^{\circ} \cdot 17$ \\
\hline \multirow{2}{*}{\multicolumn{2}{|c|}{$\begin{array}{c}5.00 \text { p.m. } \\
\text { Fourth day } 9.00 \text { a.m. }\end{array}$}} & $24^{\circ} \cdot 4^{\circ}$ & I. 8 & $0^{\circ} .12$ \\
\hline & & $24^{\circ} \cdot 5^{\circ}$ & I. 0 & $0^{\circ} .07$ \\
\hline
\end{tabular}

\section{EXPERIMENT 20.}

Two cucumbers (Cucumis sativus) about $12 \mathrm{~cm}$. long. Had been in warm room two days. Showed no difference in temperature before injury. One cut at 9.00 a.m.

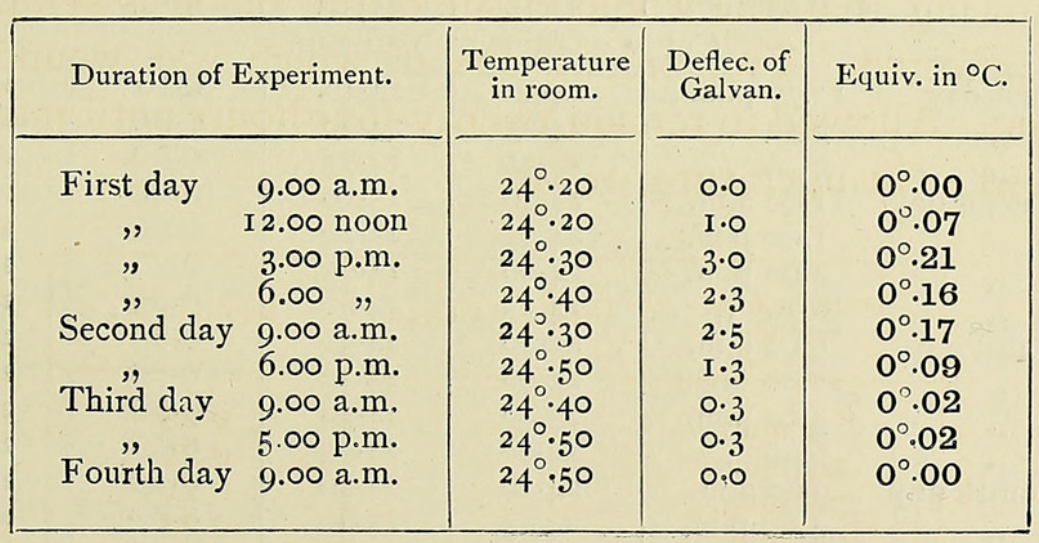


B.

The experiments recorded in this section are comparisons of the temperature of two bell-glasses, properly packed with cotton wool, one containing the uninjured, the other the injured plants. The bell-glass containing the normal plants is always designated as bell-glass $\mathrm{A}$, the other as bell-glass $\mathrm{B}$. When it was desired to determine the ordinary plus temperature shown in the bell-glass containing the uninjured objects, the other, usually bell-glass B, was filled with some substance to prevent the circulation of air, \&c., and to render all the conditions as nearly equal as possible. Vessels containing $\mathrm{KOH}$ were always placed in the bell-glasses, and the objects supported above them. Formalin was employed to prevent the growth of fungi. The thermometers used were carefully compared, and found to be precisely alike and to agree with the standard thermometer.

\section{EXPERIMENT 21.}

400 grams potatoes in each bell-glass. Had been kept in warm room two days before using. Injured by cutting into quarters.

\begin{tabular}{|c|c|c|c|c|c|}
\hline \multicolumn{2}{|c|}{ Duration of Experiment. } & \multirow{2}{*}{$\begin{array}{l}\text { Temp. Pell- } \\
\text { Glass A. }{ }^{\circ} \mathrm{C} . \\
24.40 \\
24 \cdot \mathrm{I} 5\end{array}$} & \multirow{2}{*}{$\begin{array}{l}\text { Temp. Bell- } \\
\text { Glass B. }{ }^{\circ} \mathrm{C} \text {. } \\
\\
24 \cdot 40 \\
24 \cdot \mathrm{I} 5\end{array}$} & \multirow{2}{*}{$\begin{array}{c}\text { Difference. } \\
0.00 \\
0.00\end{array}$} & \multirow{2}{*}{$\begin{array}{c}\begin{array}{c}\text { Temperature } \\
\text { outside. }{ }^{\circ} \mathrm{C} .\end{array} \\
24.00\end{array}$} \\
\hline Uninjured June & $\begin{array}{ll}\text { I } & 4.00 \text { p.m. } \\
2 & 9.00 \text { a.m. }\end{array}$ & & & & \\
\hline \multicolumn{6}{|c|}{ Cut in quarters at 9.30 a.m. } \\
\hline First day & I 2.30 p.m. & $24 \cdot 30$ & $24 \cdot 40$ & 0.10 & $23 \cdot 90$ \\
\hline 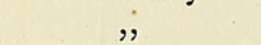 & $3 \cdot 30$, & $24 \cdot 25$ & $24 \cdot 60$ & 0.35 & 23.60 \\
\hline & 6.30, & $24: 25$ & $24 \cdot 75$ & 0.50 & $23 \cdot 70$ \\
\hline Second day & I I.00 a.m. & $24 \cdot 30$ & $25 \cdot 10$ & 0.80 & $23 \cdot 70$ \\
\hline, & I., 0 p.m. & $24 \cdot 30$ & $25 \cdot 20$ & 0.90 & $23.6_{5}$ \\
\hline, & 4.00 p.m. & $24 \cdot 20$ & $24 \cdot 95$ & 0.75 & 23.60 \\
\hline & $6.30,1$. & 24.25 & $24 \cdot 80$ & 0.65 & $23 \cdot 70$ \\
\hline Third day & 9.00 a.m. & $23: 80$ & $24 \cdot 30$ & 0.50 & $23 \cdot 40$ \\
\hline , & I 2.00 noon & 23.90 & $24 \cdot 40$ & 0.50 & $23 \cdot 20$ \\
\hline & 3.00 p.m. & 23.90 & $24 \cdot 40$ & 0.50 & $23 \cdot 40$ \\
\hline ", & 6.00, & $24 \cdot 00$ & 24.55 & 0.55 & 23.60 \\
\hline Fourth day & 9.00 a.m. & $24 \cdot \mathrm{JO}$ & $24 \cdot 50$ & 0.40 & 23.60 \\
\hline , & 4.00 p.m. & $24 \cdot 25$ & $24 \cdot 60$ & 0.35 & $23 \cdot 70$ \\
\hline Fifth day & 9.00 a.m. & $24 \cdot 30$ & $24 \cdot 65$ & 0.35 & 23.80 \\
\hline & 5.00 p.m. & $24 \cdot 30$ & $24 \cdot 50$ & 0.20 & 24.00 \\
\hline
\end{tabular}




\section{EXPERIMENT 22.}

600 grams potatoes in each bell-glass. In warm room two days before using. Washed in I \% Formalin to sterilize. Injured as in Experiment 2 $\mathrm{I}$.

\begin{tabular}{|c|c|c|c|c|c|}
\hline \multicolumn{2}{|c|}{ Duration of Experiment. } & \multirow{2}{*}{$\begin{array}{c}\begin{array}{c}\text { Temp. in } \\
\text { Bell-Glass A. }\end{array} \\
\begin{array}{r}25.80 \\
25.80\end{array}\end{array}$} & \multirow{2}{*}{$\begin{array}{c}\begin{array}{c}\text { Temp. in } \\
\text { Bell-Gilass B. }\end{array} \\
\begin{array}{r}25.80 \\
25.80\end{array}\end{array}$} & \multirow{2}{*}{$\begin{array}{c}\text { Difference. } \\
0.00 \\
0.00\end{array}$} & \multirow{2}{*}{$\begin{array}{c}\text { Temperature } \\
\text { outside. } \\
25 \cdot 30 \\
25 \cdot 35\end{array}$} \\
\hline $\begin{array}{r}\text { June } 8 \\
,, 9\end{array}$ & $\begin{array}{l}5.00 \text { p.m. } \\
9.00 \text { a.m. }\end{array}$ & & & & \\
\hline \multicolumn{6}{|c|}{ Cut in quarters at 9.10 a.m. Bell-glass B. } \\
\hline First day & I 2.00 noon & 26. 10 & 26.20 & 0.10 & $25 \cdot 60$ \\
\hline , & I.०O p.m. & $26 \cdot 20$ & 26.50 & 0.30 & $25 \cdot 65$ \\
\hline , & $3 \cdot 30$, & $26 \cdot 20$ & 26.75 & 0.55 & $25 \cdot 70$ \\
\hline , & 4.30, & $26 \cdot 25$ & $27 \cdot 00$ & 0.75 & $25 \cdot 60$ \\
\hline & $5 \cdot 30 \quad$, & $26 \cdot 35$ & $27 \cdot 20$ & 0.85 & 25.60 \\
\hline Second day & 9.00 a.m. & $26 \cdot 50$ & $27 \cdot 45$ & 0.95 & 25.65 \\
\hline ", & I I.00 , , & 26.55 & $27 \cdot 40$ & 0.85 & $25 \cdot 50$ \\
\hline , & I.Oo p.m. & 26.60 & $27 \cdot 40$ & 0.80 & $26 \cdot 10$ \\
\hline & 4.00 & 26.50 & $27 \cdot 30$ & 0.80 & 26. 10 \\
\hline Third day & 9.00 a.m. & $26 \cdot 5^{\circ}$ & $27 \cdot 20$ & 0.70 & $26 \cdot 10$ \\
\hline ", & 3.30 p.m. & 26.60 & $27 \cdot 20$ & 0.60 & $26 \cdot 20$ \\
\hline Fourth day & 8.30 a.m. & 26.60 & 27.00 & 0.40 & $26 \cdot 10$ \\
\hline Fifth day & $8.30 \quad$ & $26 \cdot 4^{0}$ & 26.60 & 0.20 & 26.00 \\
\hline
\end{tabular}

\section{EXPERIMENT 23.}

450 grams radishes (Raphamus sativus) had been two days in warm room. Washed in $\mathrm{I} \%$ Formalin. Injured by cutting longitudinally in quarters.

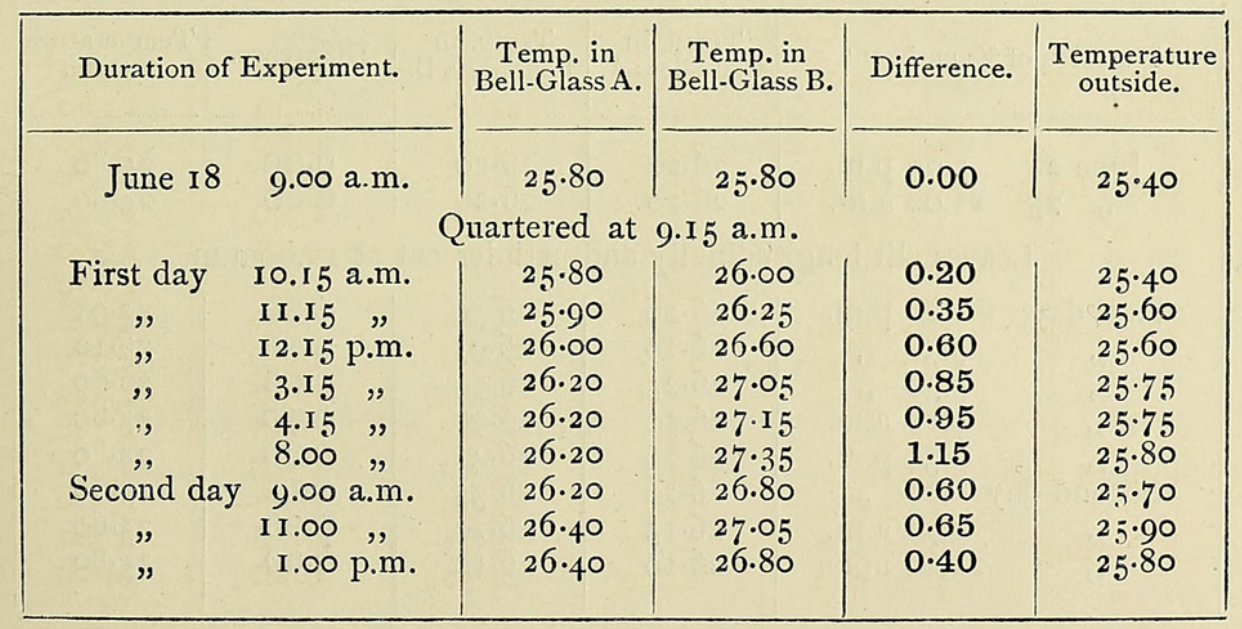




\section{EXPERIMENT 24.}

75 leaves of Diervilla sp. in each bell-glass. Weight, 50 grams. Kept in warm room fourteen hours before experiment.

\begin{tabular}{|c|c|c|c|c|c|}
\hline \multicolumn{2}{|c|}{ Duration of Experiment. } & \multirow{2}{*}{$\frac{\begin{array}{c}\text { Temp. in } \\
\text { Bell-Glass A. }\end{array}}{26.20}$} & \multirow{2}{*}{$\frac{\begin{array}{c}\text { Temp. in } \\
\text { Bell-Glass B. }\end{array}}{26 \cdot 20}$} & \multirow{2}{*}{$\begin{array}{c}\text { Difference. } \\
0.00\end{array}$} & \multirow{2}{*}{$\begin{array}{c}\begin{array}{c}\text { Temperature } \\
\text { outside. }\end{array} \\
26.10\end{array}$} \\
\hline June 20 & I 2.00 noon & & & & \\
\hline $\begin{array}{c}\text { First day } \\
, " \\
, \\
" \\
, \\
,\end{array}$ & $\begin{array}{l}\text { Leaves s } \\
\text { I.00 p.m. } \\
2.00 ", \\
3.00 ", \\
4.00 \text { " } \\
9.00 \text { a.m. } \\
\text { I } 2.00 \text { noon }\end{array}$ & $\begin{array}{l}\text { longitudina } \\
26 \cdot 20 \\
26 \cdot 20 \\
26.10 \\
26.00 \\
25.80 \\
25.80\end{array}$ & $\begin{array}{l}\text { ally at } \mathrm{I} 2.00 \\
26.20 \\
26.25 \\
26.20 \\
26.20 \\
25.90 \\
25.85\end{array}$ & $\begin{array}{l}0.00 \\
0.05 \\
0.10 \\
0.20 \\
0.10 \\
0.05\end{array}$ & $\begin{array}{l}26 \cdot 10 \\
26 \cdot 10 \\
26 \cdot 10 \\
25 \cdot 90 \\
25 \cdot 90 \\
25 \cdot 95\end{array}$ \\
\hline
\end{tabular}

\section{EXPERIMENT 25.}

Leaves and small twigs of Liriodendron tulipifera. About 70 leaves, or $\mathbf{I} 20$ grams of leaves, in each bell-glass. Had been in laboratory one day before experiment was begun. At the end of the experiment the leaves, in bell-glass $A$, were found to be still quite fresh and turgid.

\begin{tabular}{|c|c|c|c|c|c|}
\hline \multicolumn{2}{|c|}{ Duration of Experiment. } & \multirow{2}{*}{$\begin{array}{c}\begin{array}{c}\text { Temp. in } \\
\text { Bell-Glass A. }\end{array} \\
26 \cdot 20 \\
26 \cdot 20\end{array}$} & \multirow{2}{*}{$\begin{array}{c}\begin{array}{c}\text { Temp. in } \\
\text { Bell-Glass B. }\end{array} \\
26 \cdot 20 \\
26 \cdot 20\end{array}$} & \multirow{2}{*}{$\begin{array}{c}\text { Difference. } \\
0.00 \\
0.00\end{array}$} & \multirow{2}{*}{$\begin{array}{c}\begin{array}{c}\text { Temperature } \\
\text { outside. }\end{array} \\
25 \cdot 80 \\
25.80\end{array}$} \\
\hline $\begin{array}{c}\text { June } 24 \\
, \quad 25\end{array}$ & $\begin{array}{l}5.00 \text { p.m. } \\
\text { I } 1.00 \text { a.m. }\end{array}$ & & & & \\
\hline \multicolumn{6}{|c|}{ Leaves slit longitudinally and petioles cut at I I.00 a.m. } \\
\hline $\begin{array}{c}\text { First day } \\
\text { ", } \\
\text {," } \\
\text {," } \\
\text { Second day } \\
\text {," }\end{array}$ & $\begin{array}{l}\text { I.00 p.m. } \\
3.30 ", \\
5.30 \text { " } \\
9.00 \text { a.m. } \\
3.30 \text { p.m. } \\
\text { y.00 " } \\
8.30 \text { a.m. } \\
\text { I } 2.00 \text { noon }\end{array}$ & $\begin{array}{l}26 \cdot 20 \\
26 \cdot 20 \\
26 \cdot 25 \\
26.50 \\
26.20 \\
26 \cdot 20 \\
26 \cdot 15 \\
26 \cdot 10\end{array}$ & $\begin{array}{l}26 \cdot 50 \\
26.95 \\
26.90 \\
26.90 \\
26.40 \\
26.35 \\
26.20 \\
26 \cdot 10\end{array}$ & $\begin{array}{l}0.30 \\
0.75 \\
0.65 \\
0.40 \\
0.20 \\
0.15 \\
0.05 \\
0.00\end{array}$ & $\begin{array}{l}25.90 \\
26 \cdot 10 \\
26.00 \\
25.80 \\
25.80 \\
25.60 \\
25.60 \\
25.80\end{array}$ \\
\hline
\end{tabular}


EXPERIMENT 26.

45 onion-bulbs (Allium Cepa)-500 grams-in each bellglass. Had been in warm room two days before beginning of experiment. Washed objects with $1 \%$ Formalin to sterilize them.

\begin{tabular}{|c|c|c|c|c|c|}
\hline \multicolumn{2}{|c|}{ Duration of Experiment. } & \multirow{3}{*}{$\begin{array}{c}\begin{array}{c}\text { Temp. in } \\
\text { Bell-Glass A. }\end{array} \\
24 \cdot 25 \\
24 \cdot 10\end{array}$} & \multirow{3}{*}{$\begin{array}{c}\begin{array}{c}\text { Temp. in } \\
\text { Bell-Glass B. }\end{array} \\
24.20 \\
24.10\end{array}$} & \multirow{3}{*}{$\begin{array}{c}\text { Difference. } \\
-.05 \\
0.00\end{array}$} & \multirow{3}{*}{$\begin{array}{c}\begin{array}{c}\text { Temperature } \\
\text { outside. }\end{array} \\
23.90 \\
23.70\end{array}$} \\
\hline June 30 & 6.00 p.m. & & & & \\
\hline July I & 8.30, & & & & \\
\hline \multicolumn{6}{|c|}{ Onions in Bell-glass B cut into quarters at 8.45 . } \\
\hline First day & I0.30 a.m. & $24 \cdot \mathrm{I} 5$ & $24 \cdot 25$ & 0.10 & $23 \cdot 80$ \\
\hline , & II.30, , & $24 \cdot 20$ & $24 \cdot 45$ & 0.25 & 23.80 \\
\hline , & I 2.00 noon & $24 \cdot 25$ & $24 \cdot 75$ & 0.50 & $23 \cdot 90$ \\
\hline , & I $2.30 \mathrm{p} . \mathrm{m}$. & $24 \cdot 30$ & $24 \cdot 90$ & 0.60 & $23 \cdot 95$ \\
\hline , & I.०o , , & 24.50 & $25 \cdot 20$ & 0.70 & 24.00 \\
\hline , & 2.00, & $24 \cdot 65$ & $25 \cdot 55$ & 0.90 & $24 \cdot 00$ \\
\hline , & $3.30 \quad$, & $24 \cdot 55$ & $25 \cdot 90$ & 1.35 & $24 \cdot 10$ \\
\hline " & $4.30 \quad$, & $24 \cdot 60$ & $26 \cdot 20$ & 1.60 & $24 \cdot 20$ \\
\hline " & $5 \cdot 30 \quad$ & $24 \cdot 60$ & $26 \cdot 40$ & 1.80 & $24 \cdot 20$ \\
\hline " & $7 \cdot 30$, & $24 \cdot 70$ & $26 \cdot 65$ & 1.95 & $24 \cdot 10$ \\
\hline " & $9 \cdot 30 \quad$, & $24 \cdot 80$ & $27 \cdot 20$ & 2.40 & 24.05 \\
\hline Second day & 8.00 a.m. & $25 \cdot 50$ & $28 \cdot 70$ & 3.20 & $25 \cdot 10$ \\
\hline ," & 10.00 & $25 \cdot 50$ & $28 \cdot 80$ & 3.30 & $25 \cdot 10$ \\
\hline , & 4.00 p.m. & $25 \cdot 50$ & $28 \cdot 30$ & 2.80 & $25 \cdot 20$ \\
\hline Third day & 9.00 a.m. & $24 \cdot 40$ & $25 \cdot 60$ & $1 \cdot 20$ & $24 \cdot 20$ \\
\hline , & 4.00 p.m. & $24 \cdot 40$ & $25 \cdot 40$ & 1.00 & $24 \cdot 15$ \\
\hline Fourth day & 9.00 a.m. & $24 \cdot 40$ & $25 \cdot 00$ & 0.60 & $24 \cdot 00$ \\
\hline " & I. .00 p.m. & $24 \cdot 40$ & $24 \cdot 85$ & 0.45 & $24 \cdot 10$ \\
\hline " & 5.00, & $24 \cdot 30$ & $24 \cdot 55$ & 0.25 & $24 \cdot 00$ \\
\hline Fifth day & I 0.00 a.m. & $24 \cdot 40$ & $24 \cdot 50$ & 0.10 & $24 \cdot 20$ \\
\hline
\end{tabular}




\section{EXPERIMENT 27.}

500 grams small onion-bulbs (Allium Cepa), $3 \mathrm{~cm}$. in diameter, in each bell-glass. In warm room three days before beginning of experiment. Washed with Formalin to sterilize.

\begin{tabular}{|c|c|c|c|c|c|}
\hline \multicolumn{2}{|c|}{ Duration of Experiment. } & \multirow{3}{*}{$\begin{array}{c}\begin{array}{c}\text { Temp. in } \\
\text { Bell-Glass A. }\end{array} \\
26 \cdot 40 \\
26.80\end{array}$} & \multirow{3}{*}{$\begin{array}{c}\begin{array}{c}\text { Temp. in } \\
\text { Bell-Glass B. }\end{array} \\
26.40 \\
26.80\end{array}$} & \multirow{2}{*}{$\frac{\text { Difference. }}{0.00}$} & \multirow{2}{*}{$\frac{\begin{array}{c}\text { Temperature } \\
\text { outside. }\end{array}}{25 \cdot 20}$} \\
\hline July Io & 5.00 p.m. & & & & \\
\hline July II & 9.00 a.m. & & & 0.00 & 25.80 \\
\hline \multicolumn{6}{|c|}{ Cut onions in Bell-glass B in quarters 9.I 5 a.m. } \\
\hline First day & II.30 a.m. & $26 \cdot 80$ & $27 \cdot 10$ & 0.30 & $25 \cdot 80$ \\
\hline ", & I.3० p.m. & $26 \cdot 80$ & $27 \cdot 45$ & 0.65 & $25 \cdot 70$ \\
\hline ", & $3.30 "$ & 26.85 & $28 \cdot 20$ & 1.35 & $25 \cdot 70$ \\
\hline$"$ & $7 \cdot 30 "$ & $26 \cdot 80$ & $27 \cdot 40$ & 1.60 & $25 \cdot 70$ \\
\hline$"$ & $9 \cdot 30$, & $26 \cdot 80$ & $27 \cdot 70$ & 1.90 & $25 \cdot 80$ \\
\hline Second day & I0.00 a.m. & 26.85 & $28 \cdot 95$ & $2 \cdot 10$ & $25 \cdot 70$ \\
\hline , & I 2.00 noon & $26 \cdot 90$ & $29 \cdot 20$ & $2 \cdot 30$ & $25 \cdot 80$ \\
\hline$"$ & 6.00 p.m. & $26 \cdot 95$ & $28 \cdot 95$ & 2.00 & $25 \cdot 80$ \\
\hline ," & 9.00, & 27.00 & 28.80 & 1.80 & 25.90 \\
\hline Third day & 8.00 a.m. & 27.00 & 28.10 & 1.10 & $25 \cdot 90$ \\
\hline ", & I 2.00 noon & 27.00 & 27.80 & 0.80 & 25.90 \\
\hline " & 6.00 p.m. & $26 \cdot 90$ & $27 \cdot 70$ & 0.80 & $25 \cdot 80$ \\
\hline Fourth day & 8.00 a.m. & 26.80 & $27 \cdot 30$ & 0.50 & $25 \cdot 70$ \\
\hline " & I.00 p.m. & 26.80 & $27 \cdot 25$ & 0.45 & 25.80 \\
\hline " & $6.00 \quad$, & $26 \cdot 85$ & 27.05 & 0.20 & $25 \cdot 90$ \\
\hline Fifth day & $9.3 \circ$ a.m. & 26.90 & 27.00 & 0.10 & 25.80 \\
\hline \multicolumn{6}{|c|}{$\begin{array}{c}\text { The onions in Bell-glass B were removed and then replaced with coke. } \\
\text { The temperature of the bell-glass with living onions above that } \\
\text { of the other is shown below. }\end{array}$} \\
\hline Evening & 5.00 p.m. & 26.80 & 25.60 & 1.20 & $25 \cdot 70$ \\
\hline Next morni & lg 9.00 a.m. & .26 .90 & $25 \cdot 80$ & 1.10 & 25.80 \\
\hline
\end{tabular}




\section{EXPERIMENT 28.}

500 grams onion-bulbs (Allium Cepa), from $2-3 \mathrm{~cm}$. in diameter, in each bell-glass. In warm room two days before using. Washed in $1 \%$ Formalin to sterilize. Injured as in Experiment 27.

\begin{tabular}{|c|c|c|c|c|c|}
\hline \multicolumn{2}{|c|}{ Duration of Experiment. } & \multirow{3}{*}{$\begin{array}{c}\begin{array}{c}\text { Temp. in } \\
\text { Bell-Glass A. }\end{array} \\
27.00 \\
27.00\end{array}$} & \multirow{3}{*}{$\begin{array}{c}\begin{array}{c}\text { Temp. in } \\
\text { Bell-Glass B. }\end{array} \\
27.05 \\
27.00\end{array}$} & \multirow{3}{*}{$\begin{array}{c}\text { Difference. } \\
0.05 \\
0.00\end{array}$} & \multirow{2}{*}{$\frac{\begin{array}{c}\text { Temperature } \\
\text { outside. }\end{array}}{26.40}$} \\
\hline July I4 & 5.00 p.m. & & & & \\
\hline , I 5 & 8.00 a.m. & & & & $26 \cdot 40$ \\
\hline \multicolumn{6}{|c|}{ Cut onions in Bell-glass B in quarters 9.00 a.m. } \\
\hline First day & $\mathrm{r} 0.45$ a.m. & 27.00 & $27 \cdot 00$ & 0.00 & $26 \cdot 40$ \\
\hline , & I 2.45 p.m. & $27 \cdot 00$ & $27 \cdot 30$ & 0.30 & $26 \cdot 45$ \\
\hline " & 2.45, & 27.00 & $27 \cdot 60$ & 0.60 & $26 \cdot 35$ \\
\hline , & 4.45, & $27 \cdot 10$ & $27 \cdot 95$ & 0.85 & $26 \cdot 40$ \\
\hline ", & 6.45, & $27 \cdot 10$ & $28 \cdot 20$ & 1.10 & $26 \cdot 40$ \\
\hline$"$ & $8.45 ”$ & $27 \cdot 10$ & $28 \cdot 70$ & 1.60 & $26 \cdot 4^{\circ}$ \\
\hline " & 10.45, & $27 \cdot 10$ & 29.10 & 2.00 & $26 \cdot 30$ \\
\hline Second day & $\mathrm{I} 0.45$ a.m. & 27.00 & 30.15 & 3.15 & $26 \cdot 30$ \\
\hline " & I I. $45 "$ & 27.00 & $30 \cdot 35$ & 3.35 & $26 \cdot 30$ \\
\hline$"$ & I 2.45 p.m. & $27 \cdot 00$ & 30.40 & 3.40 & $26 \cdot 30$ \\
\hline , & 2.45, & 27.00 & $30 \cdot 40$ & 3.40 & 26.40 \\
\hline$"$ & $4.45 "$ & 27.05 & 30.05 & 3.00 & $2 \cdot 40$ \\
\hline , & $6.45 ”$ & 27.05 & 30.05 & 3.00 & $26 \cdot 40$ \\
\hline Third day & 8.45 a.m. & $27 \cdot 10$ & 29.90 & 2.80 & 26.50 \\
\hline$"$ & $10.45 "$ & $27 \cdot 10$ & $29 \cdot 70$ & 2.60 & 26.50 \\
\hline , & 2.45 p.m. & 27.05 & $29 \cdot 35$ & $2 \cdot 30$ & $26 \cdot 30$ \\
\hline \multirow[t]{2}{*}{$"$} & 6.45, & 27.00 & 29.00 & 2.00 & 26.20 \\
\hline & \multicolumn{5}{|c|}{$\begin{array}{l}\text { Onions in Bell-glass B removed as in Expt. } 27 . \\
\text { Difference equals }+ \text { temperature of Bell-glass A. }\end{array}$} \\
\hline Evening & Io p.m. & 27.00 & 26.25 & 0.75 & 26.20 \\
\hline \multicolumn{2}{|c|}{ Next morning } & $27 \cdot 10$ & $26 \cdot 50$ & 0.60 & $26 \cdot 35$ \\
\hline
\end{tabular}




\section{EXPERIMENT 29.}

750 grams-20-small carrots (Daucus Carota) in each bell-glass. Had been three days in warm room. Washed with $\mathrm{I} \%$ Formalin.

\begin{tabular}{|c|c|c|c|c|c|}
\hline \multicolumn{2}{|c|}{ Duration of Experiment. } & \multirow{3}{*}{$\begin{array}{c}\begin{array}{c}\text { Temp. in } \\
\text { Bell-Glass A. } \\
{ }^{\circ} \mathrm{C} .\end{array} \\
25 \cdot 80 \\
25 \cdot 80\end{array}$} & \multirow{3}{*}{$\begin{array}{c}\begin{array}{c}\text { Temp. in } \\
\text { Bell-Glass } \mathrm{D} . \\
{ }^{\circ} \mathrm{C} .\end{array} \\
25.80 \\
25.80\end{array}$} & \multirow{3}{*}{ 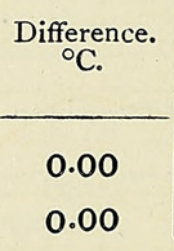 } & \multirow{2}{*}{$\begin{array}{l}\text { Tempera ture } \\
\text { outside. }{ }^{\circ} \mathrm{C} \text {. } \\
25^{\circ} 00\end{array}$} \\
\hline July 6 & $7 \cdot 30$ a.m. & & & & \\
\hline " & I I.00 , & & & & 25.00 \\
\hline \multicolumn{6}{|c|}{ Cut carrots in Bell-glass B in quarters. } \\
\hline First day & 3.00 p.m. & 25.80 & 25.90 & 0.10 & 25.00 \\
\hline ", & $5.00 "$ & $25 \cdot 70$ & $26 \cdot 20$ & 0.50 & 24.90 \\
\hline " & $7.00 \%$ & 25.60 & $26 \cdot 40$ & 0.80 & 24.90 \\
\hline " & 8.00 a.m. & 25.50 & 26.70 & 1.20 & $24 \cdot 60$ \\
\hline , & 10.00, & $25 \cdot 4^{\circ}$ & 26.65 & 1.25 & $24 \cdot 60$ \\
\hline " & I 2.00 noon & $25 \cdot 40$ & $26 \cdot 75$ & 1.35 & $24 \cdot 70$ \\
\hline$"$ & 2.00 p.m. & 25.40 & $26 \cdot 40$ & 1.00 & $24 \cdot 50$ \\
\hline Second day & 4.00 & $25 \cdot 35$ & $26 \cdot 20$ & 0.85 & 24.50 \\
\hline , & 6.00, & $25 \cdot 35$ & $26 \cdot 15$ & 0.80 & $24 \cdot 60$ \\
\hline , & 8.00, & $25 \cdot 40$ & 26.00 & 0.60 & $24 \cdot 70$ \\
\hline ", & $9 . c 0$ a.m. & $25 \cdot 45$ & 26.05 & 0.60 & $24 \cdot 80$ \\
\hline , & I.०o p.m. & $25 \cdot 30$ & $25 \cdot 80$ & 0.50 & $24 \cdot 80$ \\
\hline Third day & 5.00, & $25 \cdot 20$ & 25.60 & 0.40 & $24 \cdot 60$ \\
\hline ," & I0.00 a.m. & $25 \cdot 40$ & $25 \cdot 55$ & 0.15 & $24 \cdot 70$ \\
\hline Fourth day & 4.00 p.m. & $25 \cdot 40$ & $25 \cdot 40$ & 0.00 & $24 \cdot 70$ \\
\hline \multicolumn{6}{|c|}{$\begin{array}{l}\text { The carrots in Bell-glass B were removed and replaced by coke to } \\
\text { compare temperature in Bell-glass A with surrounding air. }\end{array}$} \\
\hline Evening & 7.00 p.m. & $25 \cdot 40$ & $24 \cdot 65$ & 0.75 & $24 \cdot 70$ \\
\hline Next morning & 10.00 a.m. & 25.60 & $24 \cdot 80$ & 0.80 & $24 \cdot 80$ \\
\hline
\end{tabular}




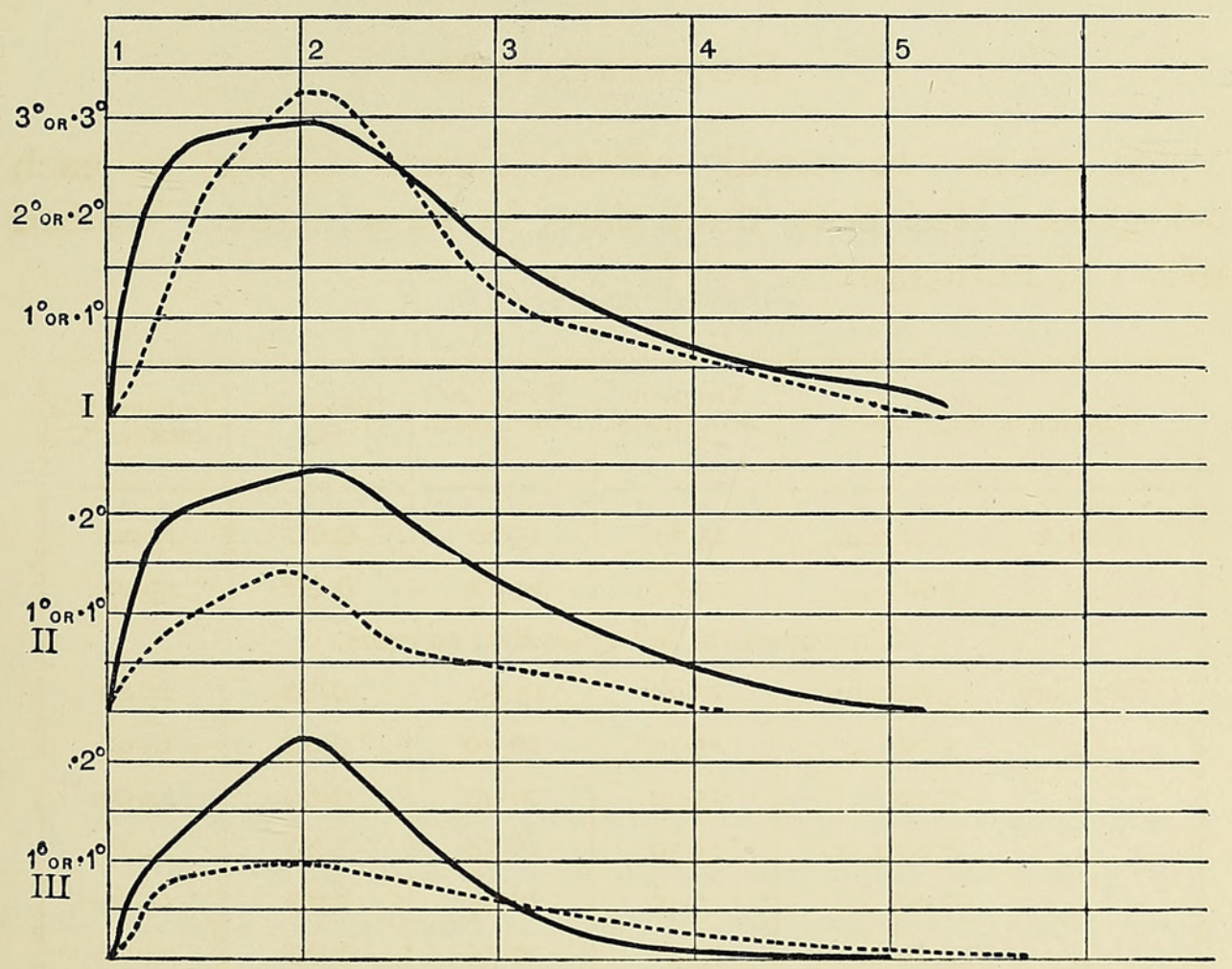

Woodcut 2.

Approximate temperature-curves of wounded plants. The solid lines are the curves obtained with the thermo-element, the dotted ones those from the bellglass experiments. With the former the value of each division is $0.05^{\circ} \mathrm{C}$, with the latter $0.5^{\circ} \mathrm{C}$. The vertical lines show the days from time of injury.
I. Onion-bulbs, Expts. 17 and 28.
II. Carrots, Expts. 15 and 29.

III. Potatoes, Expts. 4 and 22.

Compare previous paper, 1 . c., Woodcut 3 , p. $5^{82}$.

Postscript.-Since the MS. of this paper was sent to the printer, a résume, by Prof. Pfeffer, of this and the previous article on respiration has appeared in Berichte der math.-physisch. Classe d. Königl. Sächs. Gesell. zu Leipzig, Sitzung vom 27 . Juli 1896 . 


\section{$2 \mathrm{BHL}$ Biodiversity Heritage Library}

Richards, Herbert M. 1897. "The evolution of heat by wounded plants (MISSING-but in original sheet)." Annals of botany 11, 29-63. https://doi.org/10.1093/oxfordjournals.aob.a088643.

View This Item Online: https://www.biodiversitylibrary.org/item/233542

DOI: https://doi.org/10.1093/oxfordjournals.aob.a088643

Permalink: https://www.biodiversitylibrary.org/partpdf/318452

\section{Holding Institution}

Smithsonian Libraries

\section{Sponsored by}

Biodiversity Heritage Library

\section{Copyright \& Reuse}

Copyright Status: Not in copyright. The BHL knows of no copyright restrictions on this item.

This document was created from content at the Biodiversity Heritage Library, the world's largest open access digital library for biodiversity literature and archives. Visit BHL at https://www.biodiversitylibrary.org. 